\title{
Squash root microbiome transplants and metagenomic inspection for in situ arid adaptations
}

Cristóbal Hernández-Álvarez ${ }^{1,2}$, Felipe García-Oliva ${ }^{3}$, Rocío Cruz-Ortega ${ }^{4}$, Miguel F. Romero", Hugo R. Barajas ${ }^{1}$, Daniel Piñero ${ }^{5}$, and Luis D. Alcaraz ${ }^{1 *}$

${ }^{1}$ Laboratorio de Genómica Ambiental, Departamento de Biología Celular, Facultad de Ciencias, Universidad Nacional Autónoma de México.

${ }^{2}$ Posgrado en Ciencias Biológicas, Universidad Nacional Autónoma de México.

${ }^{3}$ Instituto de Investigaciones en Ecosistemas y Sustentabilidad. Universidad Nacional Autónoma de México.

${ }^{4}$ Departamento de Ecología Funcional, Instituto de Ecología, Universidad Nacional Autónoma de México

${ }^{5}$ Departamento de Ecología Evolutiva, Instituto de Ecología, Universidad Nacional Autónoma de México.

*Correspondence author: lalcaraz@ciencias.unam.mx

Please cite this article as: C. Hernández-Álvarez, F. García-Oliva, R. Cruz-Ortega, et al., Squash root microbiome transplants and metagenomic inspection for in situ arid adaptations, Science of the Total Environment (2021), https://doi.org/10.1016/j.scitotenv.2021.150136

(C) 2021, This manuscript version is made available under the CC-BY-NC-ND license http://creativecommons.org/licenses/by-nc-nd/4.0/ 


\section{Graphical abstract}

In situ sampling

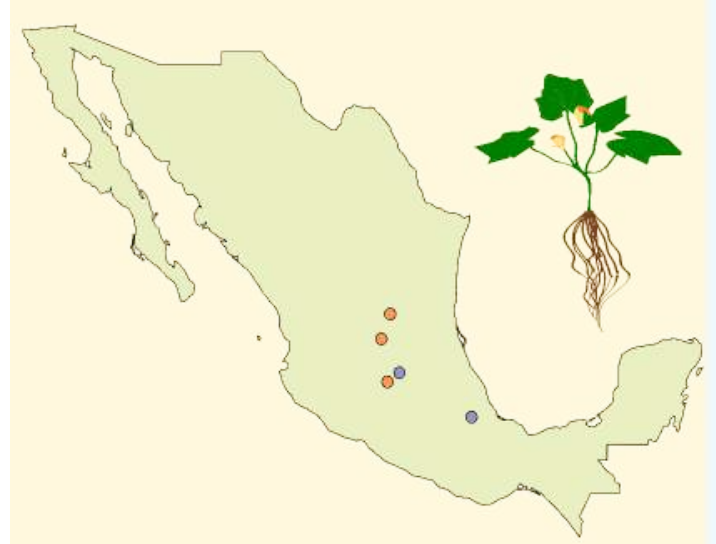

Plant phenotype measurements

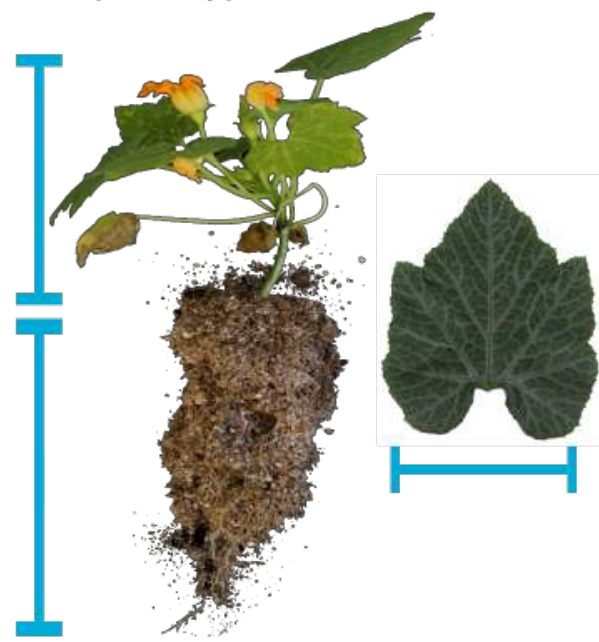

Greenhouse common garden experiment
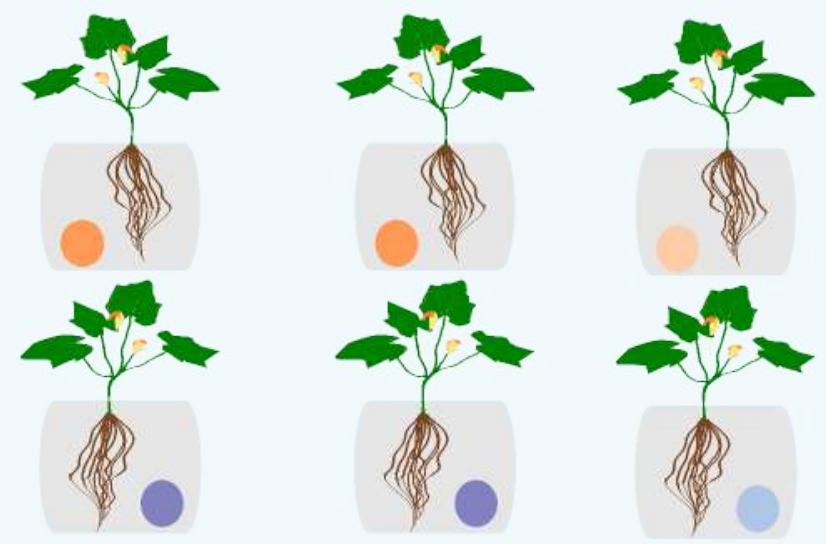

Sterilized

controls inoculant

Microbiome (16S rRNA) and metagenomic sequencing
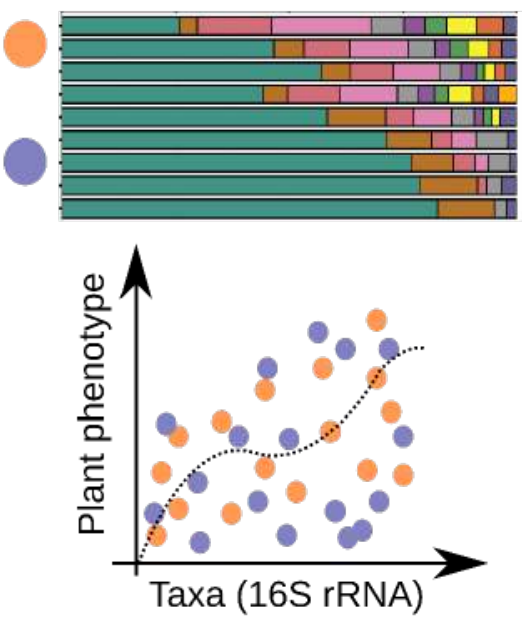

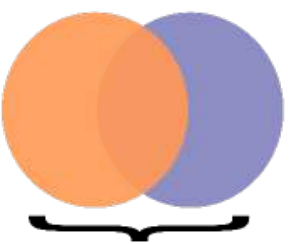

Squash microbiome and metagenome

Arid soil

Humid soil

Substrate

\section{Highlights}

- We studied squash root microbiomes and their adaptations to arid environments.

- In situ collected soil was the primary microbial inoculant for a greenhouse common garden experiment.

- Bacterial diversity from the greenhouse resembled in situ bacterial communities.

- We described beneficial bacteria communities and their drought-resistance genes in squash roots.

- Microbes from arid soils are a promissory resource for plant management under drought. 


\section{Abstract}

Arid zones contain a diverse set of microbes capable of survival under dry conditions, some of which can form relationships with plants under drought stress conditions to improve plant health. We studied squash (Cucurbita pepo L.) root microbiome under historically arid and humid sites, both in situ and performing a common garden experiment. Plants were grown in soils from sites with different drought levels, using in situ collected soils as the microbial source. We described and analyzed bacterial diversity by $16 \mathrm{~S}$ rRNA gene sequencing $(\mathrm{N}=48)$ from the soil, rhizosphere, and endosphere. Proteobacteria were the most abundant phylum present in humid and arid samples, while Actinobacteriota abundance was higher in arid ones. The -diversity analyses showed split microbiomes between arid and humid microbiomes, and aridity and soil $\mathrm{pH}$ levels could explain it. These differences between humid and arid microbiomes were maintained in the common garden experiment, showing that it is possible to transplant in situ diversity to the greenhouse. We detected a total of 1009 bacterial genera; 199 exclusively associated with roots under arid conditions. By $16 S$ and shotgun metagenomics, we identified dry-associated taxa such as Cellvibrio, Ensifer adhaerens, and Streptomyces flavovariabilis. With shotgun metagenomic sequencing of rhizospheres $(N=6)$, we identified 2,969 protein families in the squash core metagenome and found an increased number of exclusively protein families from arid (924) than humid samples (158). We found arid conditions enriched genes involved in protein degradation and folding, oxidative stress, compatible solute synthesis, and ion pumps associated with osmotic regulation. Plant phenotyping allowed us to correlate bacterial communities with plant growth. Our study revealed that it is possible to evaluate microbiome diversity ex-situ and identify critical species and genes involved in plant-microbe interactions in historically arid locations.

\section{Keywords}

Arid ecosystems, Rhizosphere, Root endosphere, Squash (Cucurbita pepo), Microbiome, Metagenomics. 


\section{Introduction}

One of the most significant challenges for the agricultural industry is climatic change, which can significantly affect yields in tropical areas as temperatures increase (Porter et al., 2014; Rosenzweig et al., 2014). Besides, climatic change may shrink areas with temperate and humid climates by increasing arid zones and minimizing the extension of lands suitable for agriculture at lower latitude locations (Dai 2013; Zarch et al., 2017; Zhang and Cai 2011). In this regard, to face problems that will result from climate change, organisms adapted to adverse conditions have the potential to be useful (Alsharif et al., 2020; Porter et al., 2014).

The bacterial diversity of soils is driven by biotic and abiotic factors that lead to spatial heterogeneity in the distribution of soil organisms (Comeau et al., 2020; Ettema and Wardle, 2002). Some abiotic parameters affecting the structure of the soil bacterial communities are $\mathrm{pH}$, nutrient availability, salinity, soil texture, and aridity (Kaiser et al., 2016; Neilson et al., 2017; Peralta et al., 2013). Desert soils are ecosystems harboring a diverse set of bacterial species capable of surviving under drought conditions (Heulin et al., 2017; Lebre et al., 2017; Naylor and Coleman-Derr, 2018). As arid soils are oligotrophic ecosystems, soil microbial communities have a greater abundance of genes involved in the degradation of recalcitrant carbon sources (Naylor et al., 2017). Some soil bacteria can interact with plant roots, specifically within the rhizosphere and root endosphere, and the rhizosphere is the soil region directly in contact with plant root secretions (Bulgarelli et al., 2013; Sasse et al., 2018). The root endosphere is the microbial niche inside plant roots (Bulgarelli et al., 2013; Sasse et al., 2018). Given the observed pattern of reduction in bacterial diversity from soil to root (Comeau et al., 2020; Lundberg et al., 2012), a two-step microbiome selection model emerged (Bulgarelli et al., 2013). In the first step, soil properties shape microbial communities; in the second step, the plant selects its root-interacting bacteria by molecular signs as plant root exudates and the bacterial ability to interact with the plant cell wall host immune system (Bulgarelli et al., 2013). Several studies have described bacterial diversity from roots of plants in drought conditions, showing an increase in the abundance of Actinobacteriota (Fitzpatrick et al., 2018; Naylor et al., 2017; Naylor and Coleman-Derr, 2018; Santos-Medellín et al., 2017; Xu et al., 2018) which could be actively be recruited by root exudates (Xu et al., 2018). 
Although not all interactions between bacteria and roots are beneficial for plants (Müller et al., 2016); some microbes from arid lands have the potential to facilitate plant growth under harsh conditions by improving plant health and enhancing resistance to high temperatures, low humidity, and elevated concentrations of salts (Alsharif et al., 2020; Soussi et al., 2016). Physiological adaptations to drought lead to differences between bacterial communities from deserts and other terrestrial ecosystems (Fierer et al., 2012; Neilson et al., 2017). Generally speaking, Acidobacteriota, Proteobacteria, and Planctomycetota bacterial phyla are associated with wet soils, while Actinobacteriota increases with aridity (Neilson et al., 2017). Actinobacteriota remains highly abundant in soils from arid localities because they are Gram-positive microbes with thick cell walls that tolerate desiccation (Naylor et al., 2017; Uroz et al., 2013; Xu et al., 2018).

In this work, we analyzed the root-associated microbiome (16S rRNA gene) and selected shotgun metagenomes of squash (Cucurbita pepo L.) in sites with different aridity levels to obtain microbial communities with the potential to improve plant survival to drought conditions. We studied squash plants because of their agricultural, economic, and gastronomic relevance (Eguiarte et al., 2018), but our experimental design can be applied to other plant species. We aimed to study and recover local diversity from arid ecosystems via a common garden experiment. The common garden experiment is a medium to study local adaptation, where individuals from different populations are grown in a common environment to study the relationships between phenotype, genotype, and environment (de Villemereuil et al. 2016). The existence of contrasting environments favors the study of local adaptation, and a common garden is a tool that allows researching the genetic basis of the phenotypes regardless if they are adaptive or not (de Villemereuil et al., 2016). We consider the microbiome as an extended plant phenotypic plasticity, with implications to plant local adaptation to its environment (Vannier et al., 2015; Partida-Martínez and Heil 2011; Y. Li et al. 2018). Here, we collected microbial communities from different habitats and then transplanted them to the same environment, a greenhouse, a common garden in a microbiological context (Reed and Martiny et al., 2007). Our common garden experiment evaluated the relationship between the microbiome and the plant's phenotype by growing squash plants in pots 
inoculated with the transplanted microbial communities. Finally, shotgun metagenomic analyses suggest that root-associated communities from arid sites possess genes to establish plants' interactions and survive drought.

\section{Materials and Methods}

\subsection{In situ sampling}

We chose five localities with active Cucurbita pepo farming (CONABIO, 2018), belonging to three soil groups, and due to their contrasting humidity climatic information (Table 1) (Fernández Eguiarte et al., 2014). We calculated Lang's aridity index (Al) (Quan et al., 2013). $\mathrm{Al}$ is the ratio of annual precipitation to mean annual temperature. Following their Al values, we classified the localities as arid $(\mathrm{Al}<40)$ or humid ( $\mathrm{Al}>40)$ (Quan et al., 2013) (Table 1). We collected from the in situ cultivated, C. pepo plants roots (triplicates), and bulk soil samples collected to fill $50 \mathrm{~mL}$ sterile centrifuge tubes from these localities. Samples were immediately liquid nitrogen frozen and stored at $-80^{\circ} \mathrm{C}$ in the laboratory until metagenomic DNA extraction. Additionally, we collected $1 \mathrm{~kg}$ of soil at $10 \mathrm{~cm}$ depth for a common garden experiment, and we kept the soil at $4^{\circ} \mathrm{C}$ until greenhouse use.

Table 1. Sampling locations and physicochemical characterization of soils.

\begin{tabular}{|c|c|c|c|c|c|c|c|c|c|c|c|c|c|}
\hline & $\begin{array}{c}\text { In situ } \\
\text { location }\end{array}$ & Al & Latitude & Longitude & $\begin{array}{l}\text { Soil } \\
\text { order }\end{array}$ & $\mathrm{pH}$ & $\begin{array}{c}\text { TOC } \\
(\mathrm{mg} / \mathrm{g})\end{array}$ & $\begin{array}{c}\mathrm{TN} \\
(\mathrm{mg} / \mathrm{g})\end{array}$ & $\begin{array}{c}\text { TP } \\
(\mathrm{mg} / \mathrm{g})\end{array}$ & $\begin{array}{c}\mathrm{NH}_{4} \\
(\mu \mathrm{g} / \mathrm{g})\end{array}$ & $\begin{array}{c}\mathrm{NO}_{3} \\
(\mu \mathrm{g} / \mathrm{g})\end{array}$ & $\begin{array}{l}\mathrm{HPO}_{4} \\
(\mu \mathrm{g} / \mathrm{g})\end{array}$ & $\begin{array}{c}\text { Collection } \\
\text { date }\end{array}$ \\
\hline \multirow{2}{*}{$\begin{array}{l}\text { Humid } \\
\text { localities }\end{array}$} & 1 & 99.4 & 18.81 & -97.08 & Vertisol & 7.1 & 26.41 & 2.12 & 0.75 & 0.35 & 46.17 & 100.36 & $2016 / 08 / 08$ \\
\hline & 2 & 50.8 & 20.39 & -100.28 & Feozem & 6.9 & 18.61 & 1.39 & 0.316 & 0.36 & 60.55 & 148.72 & $2016 / 06 / 30$ \\
\hline \multirow{3}{*}{$\begin{array}{c}\text { Dry } \\
\text { localities }\end{array}$} & 3 & 38.3 & 20.06 & -100.82 & Vertisol & 7.7 & 44.98 & 4.62 & 3.019 & 0.01 & 150.19 & 975.18 & $2016 / 06 / 30$ \\
\hline & 4 & 24.7 & 21.59 & -101.08 & Feozem & 8.5 & 50.72 & 3.52 & 0.998 & 0.36 & 60.55 & 148.72 & $2016 / 06 / 29$ \\
\hline & 5 & 21 & 22.45 & -100.70 & Xerosol & 8.5 & 12.39 & 0.87 & 0.082 & 0.34 & 88.58 & 317.68 & $2016 / 06 / 28$ \\
\hline
\end{tabular}

Sampling locations are sorted according to the aridity index (AI). Total organic carbon, TOC; total nitrogen, TN; total phosphorus, TP. 


\subsection{Soil processing and physicochemical description}

Soil samples were cleaned for large pieces of organic matter and dried in an oven at $75^{\circ} \mathrm{C}$. Then, we mixed the soil with deionized water 1:2 (w/v), and the $\mathrm{pH}$ was measured. Total and inorganic C were determined via a colorimetric method (Huffman, 1977) using a total carbon analyzer (UIC Mod. CM5012). Total organic carbon (TOC) was determined by subtracting levels of inorganic $C$ from TOC. Total nitrogen (TN) and phosphorus (TP) were quantified using a Bran-Luebbe AutoAnalyzer III (Norderstedt, Germany) following previously reported protocols (Bremner and Mulvaney, 1982; Murphy and Riley, 1962). Inorganic fractions of N $\left(\mathrm{NH}_{4}{ }^{+}\right.$and $\left.\mathrm{NO}_{3}{ }^{-}\right)$and $\mathrm{P}\left(\mathrm{H}_{2} \mathrm{PO}_{4}{ }^{-}\right)$were estimated using standard methods (Murphy and Riley, 1962).

\subsection{Common garden experiment and plants management}

The common garden experiment considered reducing plant host genetic variance using commercial Cucurbita pepo var. Zucchini F1 seeds (Hydro Environment, http://hydroenv.com.mx) minimizing environmental variance by growing them simultaneously in a greenhouse under the same conditions. We tested in situ collected soils $(N=5)$ from arid and humid conditions as microbial inoculants for plant rhizospheres. For each tested soil, germinated plants were grown in a pot filled with $90 \%$ autoclaved sterilized substrate (agrolite and vermiculite $1: 1 \mathrm{v} / \mathrm{v}$ ) and a $10 \% \mathrm{v} / \mathrm{v}$ soil inoculum ( $\mathrm{N}=8$ pots), the samples were distributed as follows: testing soil inoculants ( $n=3$ pots), fertilized soil inoculants ( $n=3$ pots), sterilized soil controls ( $n=2$ pots), and external control without inoculated soil $(n=1$ pot).

Plant seeds were previously treated with thiram fungicide by the provider. We removed the fungicide and sterilized seeds by washing with sterilized water, $70 \%$ ethanol (v/v) for $5 \mathrm{~min}$, $4.5 \%$ sodium hypochlorite $(\mathrm{w} / \mathrm{v})$ for $10 \mathrm{~min}$, and performed a final wash in deionized water. Seeds were placed on Petri dishes using humid cotton and were maintained inside a germination chamber in dark conditions at $25.5^{\circ} \mathrm{C}$ until plant cotyledons were visible. The plants were watered daily. The fertilized treatment was initiated 34 days post-germination to test the role of external fertilization in the plants and microbiomes. According to the 
manufacturer (Agrodelta, http://www.agrodelta.com.mx/), the fertilization treatment consisted of weekly doses of commercial fertilizer containing $18.2 \mathrm{mg} \mathrm{NH}_{4}{ }^{+}, 20.5 \mathrm{mg} \mathrm{P}_{2} \mathrm{O}_{5}$, and $35.1 \mathrm{mg}$ $\mathrm{K}_{2} \mathrm{O}$. Sterilization controls were obtained by autoclaving the inoculant soils. The common garden experiment ended 52 days after transplantation (Fig. S1).

\subsection{Plant phenotype measurements}

We measured foliar surface, aerial plant length, stem length, flower number, root length, stem diameter, chlorophyll, carotenoids, aerial biomass, and specific leaf area. The absorbance of each solution at 663,645 , and $440.5 \mathrm{~nm}$ was measured using a spectrophotometer (Cary 50 , Varian) to estimate chlorophyll a, b (Sudhakar et al., 2016), reported as chlorophyll, and carotenoid concentrations, as described elsewhere (Lewandowska and Jarvis, 1977). The foliar surface of specimens was determined by scanning leaves and analyzing pixel areas with ImageJ 1.x software (Schneider et al., 2012). Plant phenotype variables, including total chlorophyll and carotenoids, were measured by multiplying each pigment concentration by the plant's foliar surface area. Aerial biomass was estimated with plants dried in an oven at $50^{\circ} \mathrm{C}$. Specific leaf area was calculated as the ratio of the leaf surface area to its dry weight (Wellstein et al., 2017).

\subsection{Metagenomic DNA extraction}

The metagenomic DNA was processed as previously described (Lundberg et al., 2012; Barajas et al., 2020; Romero et al., 2021). Briefly, plant roots were fractionated and collected into tubes that contained $1.5 \mathrm{~mL}$ of phosphate-buffered saline solution (PBS) at $7.5 \mathrm{pH}$. Tubes were vigorously mixed with a vortex until soil particles detached from roots to produce the root rhizosphere. For endosphere metagenomic DNA extraction, roots were mechanically broken and transferred to fresh tubes containing PBS $(1.5 \mathrm{~mL})$ and sonicated. Samples were centrifuged at $1,300 \times \mathrm{g}$ for $10 \mathrm{~min}$ to recover the rhizosphere and endosphere. Then, the metagenomic DNA was extracted using $0.25 \mathrm{~g}$ from the soil, rhizosphere, and endosphere pellets using the MoBio PowerSoilß DNA Isolation Kit (MoBio Laboratories, Solana Beach, CA, USA) following the manufacturer's protocol. 


\subsection{S rRNA gene amplicons and metagenome sequencing}

We performed PCR amplification of the 16S rRNA gene using MiSeq341F and MiSeq805R primers, corresponding to V3-V4 regions (Herlemann et al., 2011). The amplicon also included overhangs for multiplex library preparation by the Illumina Miseq protocol (lllumina Inc., 2013). Duplicate reactions were carried out for each sample and Taq polymerase (Promega. Madison, WI, USA). The amplification program involved an initial denaturation step at $94^{\circ} \mathrm{C}$ for $3 \mathrm{~min}$; followed by five cycles that included denaturation at $94^{\circ} \mathrm{C}$ for $10 \mathrm{~s}$, annealing at $55^{\circ} \mathrm{C}$ for $20 \mathrm{~s}$, extension at $72^{\circ} \mathrm{C}$ for $30 \mathrm{~s}$; and 25 cycles of denaturation at $95^{\circ} \mathrm{C}$ for $5 \mathrm{~s}$ and extension at $72^{\circ} \mathrm{C}$ for $30 \mathrm{~s}$. Amplicons were purified using the Wizard® SV Gel and PCR Clean-up System (Promega. Madison, WI, USA).

Sequencing of the amplified region of the 16S rRNA gene was performed using Illumina 8 MiSeq $^{\mathrm{TM}}$ (Illumina, San Diego, CA, USA) hardware using a $2 \times 300$ bp configuration, following the Illumina ${ }^{\circledR}$ protocol provided by the Unidad de Secuenciación Masiva at the National Autonomous University of Mexico's Biotechnology Institute (IBT, UNAM). The whole shotgun metagenomic sequencing was performed at the Laboratorio Nacional de Genómica para la Biodiversidad (UGA-Langebio), using Illumina ${ }^{\circledR}$ NextSeq 500 (Illumina, San Diego, CA, USA) in a $2 \times 150$ bp configuration.

\subsection{Sequence processing}

The 16S rRNA gene analysis protocol used for this study had been previously reported and detailed at GitHub (https://github.com/genomica-fciencias-unam/SOP; Alcaraz et al. 2018; Hernández et al. 2020). Briefly, raw amplicon sequences were quality checked and trimmed to a length of 250 bp using FASTX-Toolkit (Gordon and Hannon, 2010). Sequences were merged with Pandaseq (Masella et al., 2012). Chimeras were removed using ChimeraSlayer (Caporaso et al., 2010). Sequence clustering of operational taxonomic units (OTUs) was performed with cd-hit-est ( $\mathrm{Li}$ and Godzik, 2006) using an identity cut-off of $97 \%$. Representative OTUs and taxonomically assignment were achieved with QIIME scripts (Caporaso et al., 2010) and BLAST (Altschul et al., 1990) the taxonomic database was SILVA v138 (Quast et al., 2013). 
Raw metagenomic sequences were mapped against the C. pepo genome (Montero-Pau et al., 2018) using Bowtie 2 (Langmead and Salzberg, 2012) and were subsequently processed using SAMtools (Li et al., 2009) to filter out plant reads. Read quality control was done using Trimmomatic (4 nt sliding windows, Phred $\geq 15,34$ bp length) (Bolger et al., 2014). Metagenomic assemblies were done with metaSpades (Nurk et al., 2017) and Velvet (Zerbino, 2010) with the k-mer size equals to 31. Coding gene sequences and predicted proteins were calculated with Prodigal (Hyatt et al., 2010). Sequences of predicted proteins were aligned with DIAMOND (Buchfink et al., 2014) against the M5nr database (Wilke et al., 2012), using RefSeq (O'Leary et al., 2016), Subsystems ontology from SEED (Overbeek et al., 2005), and the Kyoto Encyclopedia of Genes and Genomes (KEGG) (Kanehisa and Goto, 2000) annotations. Bowtie 2 (Langmead and Salzberg, 2012) was used to map reads against predicted proteins from contigs to estimate abundance. Unannotated diversity was clustered with the cd-hit ( $\mathrm{Li}$ and Godzik, 2006) at $70 \%$ identity and was used to assess metagenomic diversity. Metagenome sequences from each sample were mapped against bacterial reference genomes (O'Leary et al., 2016) using the NUCmer script from MUMmer (Marçais et al., 2018). Detailed statistical and bioinformatic methods are available at GitHub (https://github.com/genomica-fciencias-unam/squash-microbiome).

\subsection{Data analyses}

We used $R$ for all diversity and statistical tests (R Development Core Team, 2011), and graphs were plotted with ggplot2 (Wickham, 2016). For biodiversity calculations, we used phyloseq (McMurdie and Holmes, 2013) and vegan (Oksanen et al., 2019). To evaluate the relationship between microbial communities with $\mathrm{pH}, \mathrm{Al}$, and nutrient content of soils, we calculated a constrained analysis of principal coordinates (CAP) (Anderson and Willis, 2003). Differential features of both taxa and predicted proteins were calculated using DESeq2 (Love et al., 2014). Bacterial genera were correlated with phenotypic traits using the psych $R$ package (Revelle, 2017). Pathway reconstructions were created using the KEGG mapper (Kaneisa and Sato, 2020) with whole predicted proteins annotated in KEGG and those that were unique or 
overrepresented via DESeq2 analysis. Detailed statistical and bioinformatic methods are available at GitHub (https://github.com/genomica-fciencias-unam/squash-microbiome).

\subsection{Data availability}

Raw sequence data is available in the NCBI Sequence Read Archive (SRA) database. Soil sample sequence data is available with accession codes from SRR11972628 to SRR11972633; rhizosphere and endosphere sample data accessions from SRR11967772 to SRR11967813; and whole shotgun metagenomes accessions from SRR12046619 to SRR12046624.

\section{Results and discussion}

\subsection{Cucurbita root microbiome is consistent with the two step-model for plant} root microbiome acquisition

The 16S rRNA gene sequencing got us 7,476,012 paired sequences spanning $2.75 \times 10^{9} \mathrm{bp}$, merged sequences clustered into 73,277 OTUs (Table S2). Shotgun metagenomic sequencing yielded $247 \times 10^{6}$ sequences, assembled into $20 \times 10^{6}$ contigs representing $5.19 \times$ $10^{9} \mathrm{bp}$, an average GC\% of 62.7 , and N50 of $894 \mathrm{bp}$ (Table S3).

We calculated the average 16S rRNA gene diversity indexes. In most cases, soil diversity values were greatest $($ Shannon $=7.31-7.99$, Simpson $=0.996-0.999)$, followed by rhizosphere (Shannon $=3.9-7.31$, Simpson $=0.948-0.996)$, and then root endosphere $($ Shannon = 3.9-7.2, Simpson $=0.88-995)($ Fig. 1A, Table S2). Shannon and Simpson diversity indices showed statistically significant differences between soil and rhizosphere $(p<1 e-3)$, soil and endosphere $(p<1 e-4)$, but not between rhizosphere and endosphere. Thus, reducing diversity from soil to root observed in the squash microbiome is consistent with the two step-model (Bulgarelli et al., 2013). 


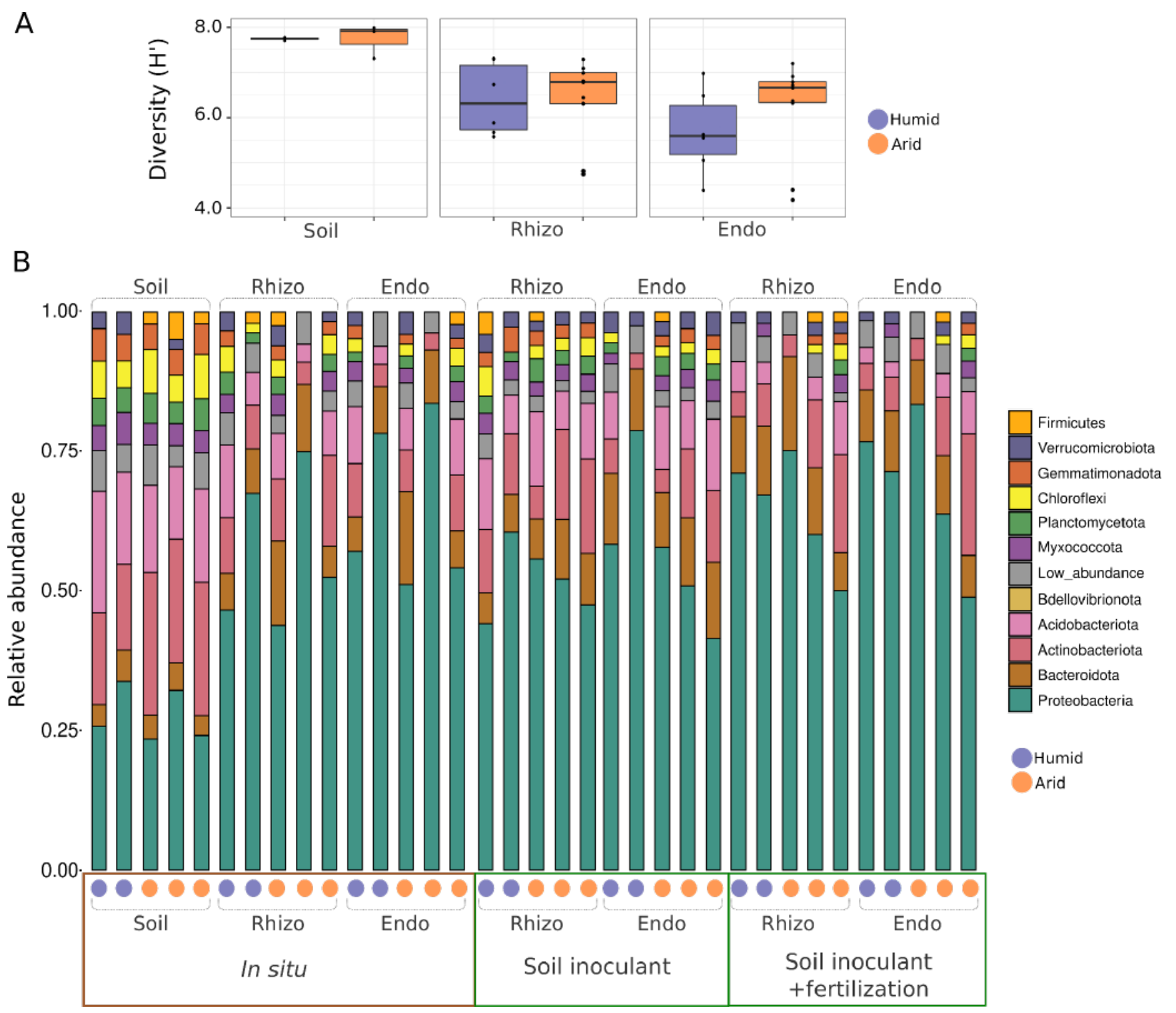

Figure 1. Squash root microbiome diversity and phyla abundance in humid and arid conditions.

A) Shannon diversity index of the soil, rhizosphere (rhizo), and root endosphere (endo). B) Most abundant phyla are sorted by climatic conditions (humid or dry) of the soil, rhizosphere, and root endosphere from in situ collected plants and the common garden experiment (soil inoculants).

Besides different diversity levels, we found 74 genera exclusive from the rhizosphere and 70 genera exclusive from the root endosphere (Table S4). Endosphere exclusive genera include the intercellular plant pathogen Pectobacterium and the root isolated endophyte Rothia (Aizawa, 2014; Xiong et al., 2013). Proteobacteria was the most abundant phylum in all 
samples assessed (Fig. 1B), particularly abundant in root endospheres (average $=76 \%$ ) and rhizospheres $(69 \%)$, while its relative abundance was lower in soils $(32 \%)$. In addition to Cucurbita pepo, plants like Medicago sativa, Solanum lycopersicum, Lotus corniculatus, Oryza glaberrima, and Oryza sativa have an increased relative abundance of Proteobacteria associated with their rhizospheres and root endospheres, which correlated with reduced levels of diversity (Bulgarelli et al., 2012; Fitzpatrick et al., 2018; Lundberg et al., 2012; Barajas et al., 2020).

\subsection{Historically arid and humid soils contain different bacterial communities}

Proteobacteria were increased in samples from historically humid origins for both in situ and the common garden experiment, while the Gram-positive Actinobacteriota and Firmicutes were elevated in historically arid conditions (Fig. 1B). We found significant differences (t-test, $p \leq 0.05$ ) in the proportion of Actinobacteriota ( $9 \%$ on average in arid samples and $5 \%$ in humid samples) and Firmicutes (1.3\% in arid samples and $0.7 \%$ in humid samples) from the root endosphere. The rise of Gram-positive bacteria (Actinobacteriota and Firmicutes) in arid localities and roots resembles previously reported community compositions (Neilson et al., 2017). The greater abundance of Gram-positive bacteria in arid sites could be because they have a thicker cell wall that makes them resistant to desiccation, and some taxa are spore-forming microorganisms (Naylor et al., 2017).

A total of 1,009 bacterial genera were classified, with 199 exclusively arid conditions, 77 from humid climates, and 733 shared in both climates (Fig. S2). Some abundant genera from arid sources, such as Yaniella, Woeseia, Salinimicrobium, were described as halotolerant (Du et al., 2016; Li et al., 2004; Nedashkovskaya et al., 2010), suggesting the specialization of these communities. We calculated significant differential OTUs via DESeq2 analysis from historically humid and arid conditions ( $p \leq 0.05$, Benjamini-Hochberg). We found genera distinctly identified from each condition like Arenimonas, Azoarcus, Algoriphagus, and Thauera (Tables S5 and S6). In arid climates, Arenimonas and Azoarcus were identified from root endospheres (Table S5). Previous reports have shown that Azoarcus can colonize roots (Chen et al., 2015), and some species are capable of nitrogen-fixing (Reinhold-Hurek et al., 1993). We expected 
the presence of Arenimonas since previous reports of isolates from soil and rhizosphere (Aslam et al., 2009; Kanjanasuntree et al., 2018). Algoriphagus and Thauera were enriched in rhizospheres (Table S6), but there are no previous reports in rhizospheres. However, some Algoriphagus were isolated from contaminated soils (Young et al., 2009), and Thauera can break down aromatic compounds (Breinig et al., 2000). Thus, both genera may play essential roles in promoting Cucurbita plant growth in polluted soils or breaking down aromatic root exudates.

\subsection{The common garden experiment recovers in situ bacterial diversity}

The Actinobacteriota increase in historically arid sites was found in situ and common garden experiments samples (Fig. 1B). A multidimensional scaling (MDS) using unweighted Unifrac distances (Lozupone et al., 2011) revealed discrete groups between historically arid and humid microbiomes. Splitting of arid and humid samples in the ordination was observed for both in situ and common garden samples, without differences between both groups (Fig. 2), supported by PERMANOVA analysis (999 permutations, $p<0.001$ ). Although fertilizer treatments reduced microbial diversity (Table S2) as previously reported (Ling et al., 2017), changes in community structure promoted by fertilizer treatments were not abrupt since fertilized communities from arid and humid sources maintained their differences (Fig. 2). Finally, sterilized controls split apart from the rest of the samples, reinforcing the idea that the differences in bacterial communities originate from the source soil, and bacterial diversity in sterilized controls is mainly the result of greenhouse management (Fig. 2). These results suggest that small inoculates of soil microbial communities from arid sites can be exported to other systems to recover key taxa adapted to drought, with communities that retain their characteristics to an extent in response to ex-situ features as nutrient supply. 


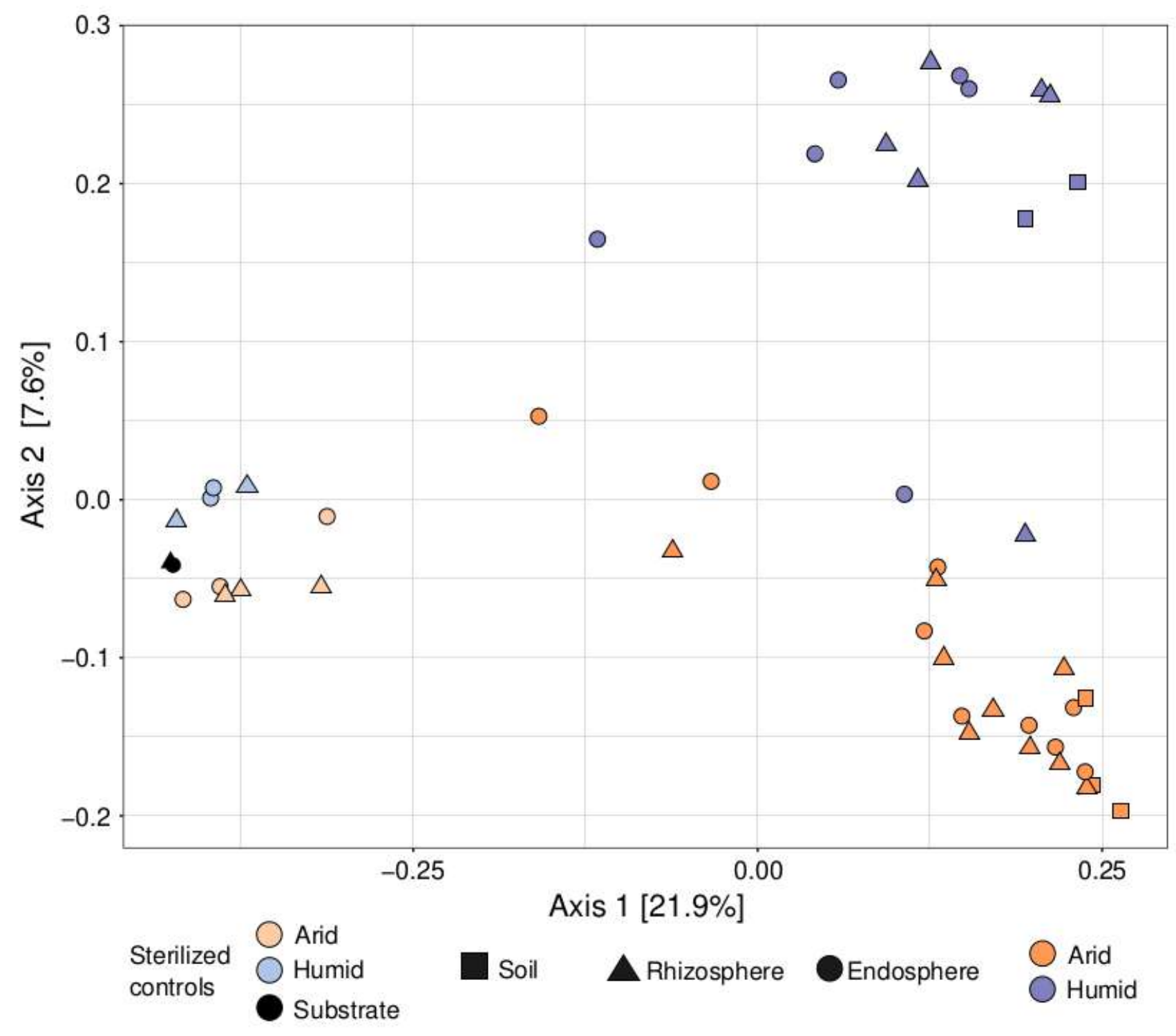

Figure 2. Squash microbiomes split according to their source environment, but the common garden and in situ samples are mixed. The -diversity is shown as unweighted Unifrac distances and plotted as multidimensional scaling (MDS) ordination, using the 16S rRNA gene amplicons data. Sterilized controls clustered at the left splitting from the soil inoculants and their soil and rhizosphere (21.9\% variance, Axis1). MDS Axis 2 splits the arid and humid microbiomes (7.6\%). The samples of soil, rhizosphere, and endosphere communities were closer to each other, regardless of in situ or common garden experiment samples.

Constrained analysis of principal coordinates (CAP) for in situ collected samples was built based on Al the physicochemical characterization of soils (Table 1). This analysis revealed that differences between humid and arid localities communities are related to $\mathrm{Al}$ and pH (Fig. 
S3). The $\mathrm{pH}$ is a good predictor of bacterial community type because living in an extreme $\mathrm{pH}$ environment limits survival (Kaiser et al., 2016). Communities that live under pH stress tend to harbor phylogenetically similar organisms (Tripathi et al., 2018) such as Acidobacteriota, whose relative abundance increases with soil acidity (Lauber et al., 2009). A recent work that assessed global bacterial distribution patterns determined that $\mathrm{pH}$, aridity, and ecosystem productivity are the best predictors of diversity (Delgado-Baquerizo et al., 2018).

Constrained analysis of principal coordinates (CAP) for in situ collected samples was built based on Al the physicochemical characterization of soils (Table 1). This analysis revealed that differences between humid and arid localities communities are related to $\mathrm{Al}$ and $\mathrm{pH}$ (Fig. S3). The $\mathrm{pH}$ is a good predictor of bacterial community type because living in an extreme $\mathrm{pH}$ environment limits survival (Kaiser et al., 2016). Communities that live under pH stress tend to harbor phylogenetically similar organisms (Tripathi et al., 2018) such as Acidobacteriota, whose relative abundance increases with soil acidity (Lauber et al., 2009). A recent work that assessed global bacterial distribution patterns determined that $\mathrm{pH}$, aridity, and ecosystem productivity are the best predictors of diversity (Delgado-Baquerizo et al., 2018).

A constrained analysis of principal coordinates (CAP) ordination of the common garden experiment was controlled by plant phenotypic traits (Table S1) and supported the same pattern observed in MDS (Fig. S3). However, the CAP ordination allowed us to associate microbiome differences with plant phenotype, showing that microbiome samples from arid environments split into a discrete group with high aridity levels correlated to plant chlorophyll and carotenoid concentrations (Fig. S3).

\subsection{Connecting root 16S rRNA gene microbiome diversity, shotgun metagenomics, and the C. pepo phenotype}

Interestingly, some differentially (DESeq2) abundant genera comparisons between climates (Tables S5 and S6) correlated with plant phenotypic features (Table S1, Fig. 3). Statistically significant differences in Spearman's correlations $(p \leq 0.05)$ revealed 25 genera of the rhizosphere and root endosphere correlated with plant phenotypes assessed (Fig. 3; Fig. S4). 
The abundance of the genus Cellvibrio positively correlates with the foliar surface $(r=0.7)$, aerial length $(r=0.7)$, stem diameter $(r=0.7)$, total chlorophyll $(r=0.8)$, carotenoid levels $(r=$ 0.7 ), and aerial biomass ( $r=0.7$ ) (Fig. 3; Fig. S4). Cellvibrio is common to plant inhabitants (Alcaraz et al., 2018; Jones et al., 2019; Zhang et al., 2020) with nitrogen fixation activity (Suarez et al., 2014) that may promote the increase of shoot biomass (Anderson and Habiger, 2012). Similarly, the relative abundance of Ensifer positively correlated with aerial biomass ( $r$ $=0.7)$, stem $(r=0.8)$, and aerial length ( $r=0.7)$ (Fig. S4). Ensifer adhaerens promote plant growth by secreting phytohormones and siderophores and solubilize phosphate (Oves et al., 2017). Ensifer was found in all root samples (rhizosphere and endosphere), highlighting this genus's relevance for $C$. pepo. Acidovorax was also ubiquitous and positively related to plant phenotype ( $r=0.7$ for carotenoids concentration) but enriched in humid samples (Fig. S4). Experimental evidence shows that Acidovorax radicis influences root and shoots weight of barley (Li et al., 2012). Thus, community members from arid locations may have plant growth promotion potential and may be relevant to protect crops from climate change-induced drought. 
A

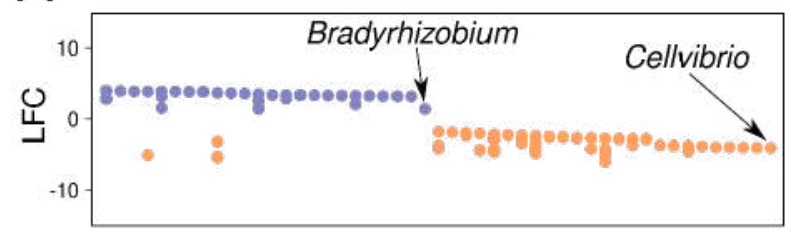

Differentially abundant taxa

B

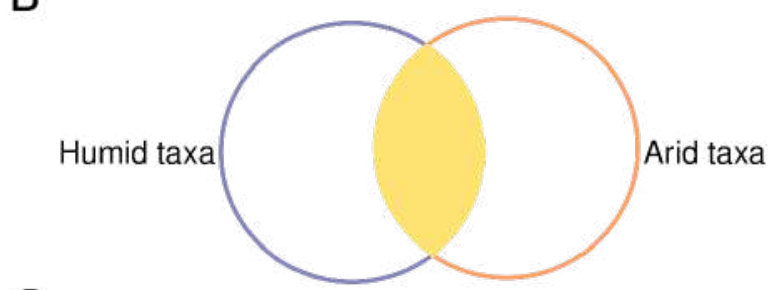

C

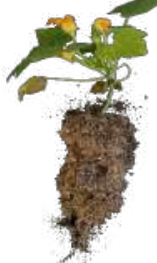

Plant phenotype

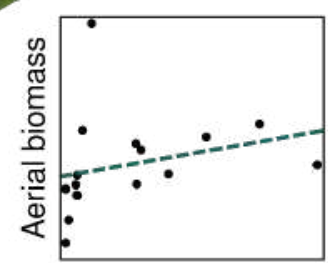

Cellvibrio

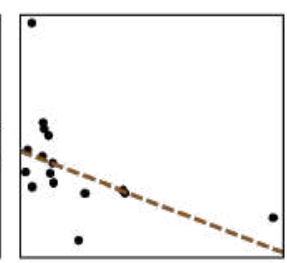

Bradyrhizobium
$16 \mathrm{~S}$ relative abundance
$\mathrm{D}$

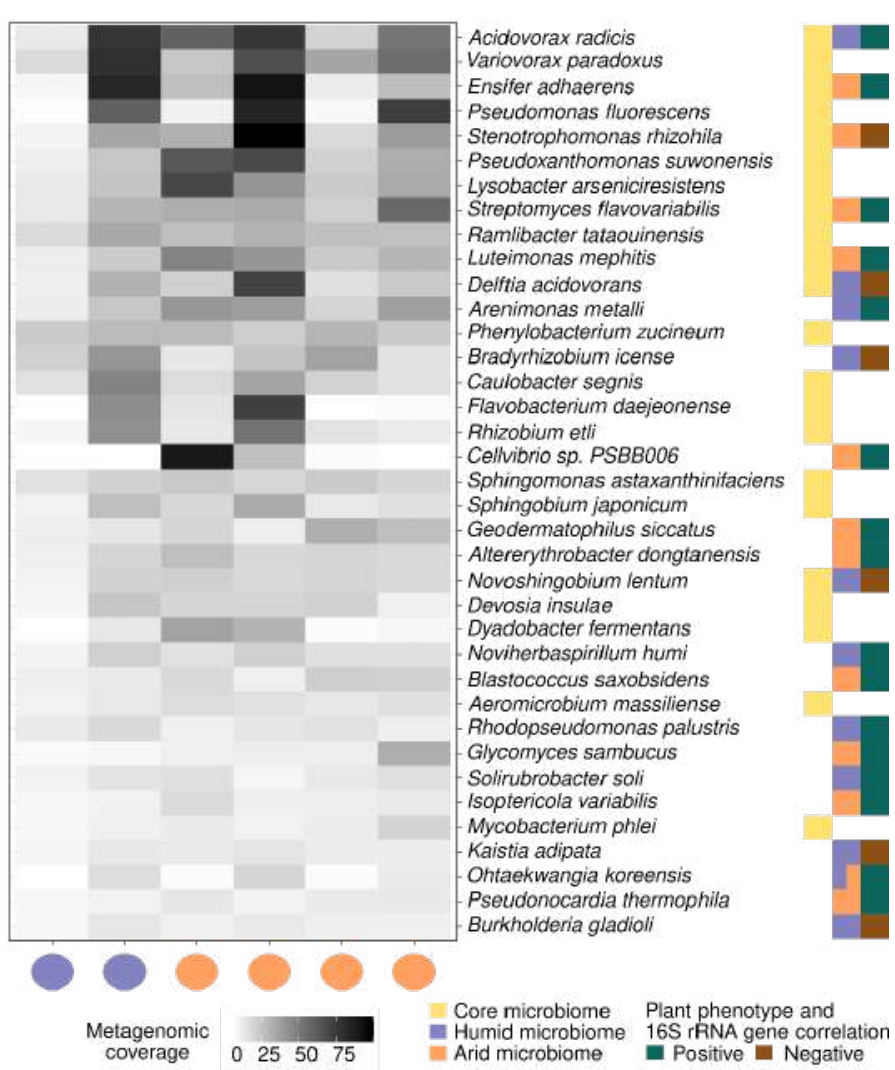

Figure 3. Connections between plant phenotype, microbiome, and metagenomic recruitments. A) Comparison and identification of significant differential OTUs ( $P \leq 0.05, F D R$ ) between arid or humid soils by contrasting their logarithmic fold change (LFC) ratio. The differential taxa are available in Tables S54 and S65. B) The squash core microbiome is defined as the intersection set of the common garden or in situ root-associated microbes (Table S76). C) Plant phenotypes were correlated with the relative abundance of genera enriched in arid or humid soils (Table S54 and S65) and plant phenotype (Table S2). D) Metagenomic binning of shotgun reads against reference bacterial genomes, in the heatmap, selected species of the same genera identified by $16 \mathrm{~S}$ rRNA gene amplicons, but now identified up to species level, validating the $16 \mathrm{~S}$ data. The metagenomic coverage is the percentage of the reference genome aligned against each metagenome. The color key indicates squash core microbiome affiliation, humid or arid $16 \mathrm{~S}$ enrichment, and phenotype correlation in the left heatmap panel.

Surprisingly, Methylobacterium and Novosphingobium traditionally described as plant symbionts (Kutschera, 2007; Rangjaroen et al., 2017; Alcaraz et al., 2018) correlated negatively with some plant phenotypic traits $(r=-0.7$ and -0.6 for chlorophyll concentration and carotenoids levels in Methylobacterium; $r=-0.8,-0.7,-0.7$, and -0.7 for foliar surface, 
total chlorophyll, total carotenoids, and aerial biomass respectively in Novosphingobium) (Fig. S4).

Additionally, we looked in the shotgun metagenomes for sequences of further evidence and validation of the bacteria correlated with plant-phenotype features. Metagenomic recruitments against reference genomes produced evidence that supported findings of the 16S rRNA gene and allowed the identification up to species (Fig. 3). Some species belonging to genera detected in all the plant roots sampled microbiomes (Table S7), such as Variovorax and Acidovorax, were identified as $V$. paradoxus and $A$. radicis, were also identified in the shotgun metagenomic reads (Fig. 3). In arid environments, metagenomic sequences of binned bacteria confirmed microbiome significantly enriched ( $p \leq 0.05$, Benjamini-Hochberg) OTUs like Cellvibrio sp. PSBB006, Stenotrophomonas rhizophila, Streptomyces flavovariabilis, Arenimonas metalli, and Glycomyces sambucus (Fig. 3). In humid environments by metagenomic binning, Delftia acidovorans and Bradyrhizobium lablabi were congruent with DESeq2 enriched OTUs (Fig. 3). The complete list of recruited genomes is available in Table S8.

Experiments using sorghum plants that analyzed the microbiome and transcriptome of root-associated bacteria revealed that plants secrete glyceraldehyde-3-phosphate to attract Actinobacteriota under drought conditions (Naylor and Coleman-Derr, 2018; Xu et al., 2018). Therefore, a pool of Actinobacteriota that are positively associated with plant traits may help plant survival under drought conditions. Streptomyces, Glymocyces, Geodermatophilus, and Pseudonocardia abundance are positively correlated with chlorophyll production. Further, a large number of metagenomic reads were binned as Actinobacteriota, remarkably Streptomyces. The high abundance of Streptomyces in our metagenomic sequencing data is outstanding but not surprising. Previous reports have described Streptomyces strains as plant growth-promoting bacteria that synthesize auxins, antibiotics, and siderophores (Sousa and Olivares, 2016), and their presence is associated with drought stress resistance (Fitzpatrick et al., 2018). 


\subsection{Cucurbita pepo microbiome genes from shotgun metagenomics reveal}

\section{differences between humid and arid soil sources}

We found coding genes and their predicted proteins used for annotation and further comparative analyses from the metagenomes. Using the Refseq derived annotations, we found a total of 1,192,784 predicted proteins from the squash metagenome, with 27,767 shared between all samples (Fig. S5). Then, using SEED classification (see Methods), we identified 2,969 predicted protein families detected in both climatic conditions, thus associated with squash in a climate-independent way. Then, 158 protein families were exclusively from humid sites, and 924 proteins were only found in arid localities (Table S9).

We compared significant differences ( $p \leq 0.05$, Benjamini-Hochberg) in gene abundances between arid or humid metagenomes using DESeq2 analysis (Fig. S5; Tables S10 and S11). We found histidine kinase (BaeS), outer membrane protease (DegS), copper sensing regulator (CpxR), and sensory histidine kinase enriched in arid sites (QseC) (Table S10). These proteins are involved in sensing and responding to extracytoplasmic stress (De Wulf et al., 2002; Nagasawa et al., 1993; Walsh et al., 2003). The activation of responses to cell envelope damage may be essential to survive the loss of membrane integrity induced by desiccation (Lebre et al., 2017). The highly abundant miscellaneous category from arid sites included geranylgeranyl/isoprenyl reductase, phosphatidylglycerophosphatase, flotillin-like YqiK Lipid A export protein (Table S9 and S10). The proteins, as mentioned earlier, may be related to membrane function in extracytoplasmic stress (Bach and Bramkamp, 2015; Lin et al., 2016; Murakami et al., 2007). Concerning the balance of osmotic pressure, we determined that proteins from arid samples related to the synthesis of compatible solutes ectoine (EctA), hydroxyectoine (EctD), ABC transporters of osmolytes choline (OpuBB), and glycine-betaine (OpuAC), trehalose, and the $\mathrm{N}(+) / \mathrm{H}(+)$ antiporter were significantly enriched or exclusive (Czech et al., 2018; Fig. S6; Tables S10, S11, and S12). The mycothiol synthase (MshD) and glutamate-cysteine ligase (involved in glutathione synthesis) were exclusive and enriched under arid conditions, respectively (Tables S9 and S10). Mycothiol and glutathione may be involved in oxidative stress resistance (Newton et al., 2008; Smirnova and Oktyabrsky, 2005) resulting from drought. Nutrient assimilation-related proteins enriched under arid conditions 
included xylanase and D-3 hydroxybutyrate oligomer hydrolase (Tables S9 and S10). These two enzymes are responsible for biopolymer breakage (Shirakura et al., 1983; Collins et al., 2005) and may degrade recalcitrant carbon sources abundant in dry oligotrophic soils (Naylor et al., 2017). The predicted proteins are part of molecular mechanisms associated with arid environments summarized into seven gene adaptations: stress sensing and response, protein degradation, osmoregulation, oxidative stress coping, cell wall, and catabolism (Fig. 4). Besides previously described categories, we predicted proteins related to chemotaxis, flagellar assembly, motility, and secretion systems type III, IV, and VI, which were identified independently of climatic conditions (Fig. S6). Chemotactic and flagellar proteins to sense and move toward plant signals and type III and IV secretion systems mediate interactions with host species (Hubber et al., 2004; Levy et al., 2018). Almost all enzymes involved in the nitrogen cycle were identified regardless of the climatic source of the samples (Fig. S6). In samples from arid sources, hydroxylamine levels could produce ammonia by the enzyme hydroxylamine reductase ( $\mathrm{Hpc}$ ), as suggested by the abundance of observed genes. In humid zones, hydroxylamine dehydrogenase (Hao) could dehydrogenate hydroxylamine to nitrite (Fig. S6). 


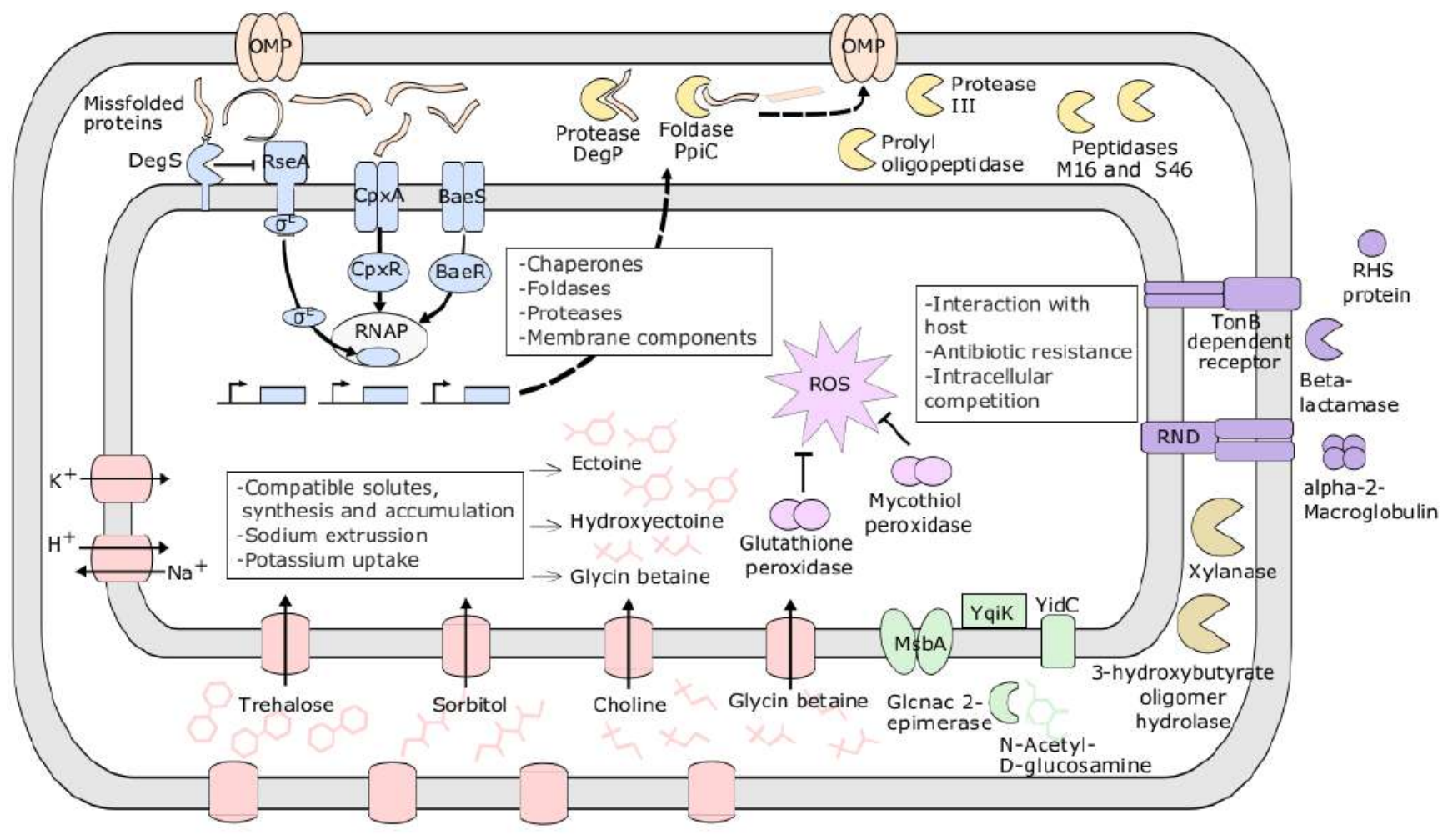

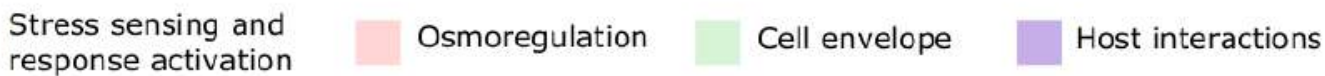

Protein degradation and recycling
Oxidative stress
Catabolism of

recalcitrant compounds

Figure 4. Cucurbita pepo's summary of microbiome adaptations to arid environments. A metabolic proposal built from the main metagenomic predicted protein features. The main identified functional categories of the metagenomic adaptations are color-coded and classified based on their molecular or cellular functions.

Other enriched proteins in the arid environment include efflux transporter RND, beta-lactamase, membrane protein insertase (YidC), the RHS family, tex-like protein, alpha-2-macroglobulin family, and the TonB-receptor (Fig. 4 Fig. S5). Alpha-2-macroglobulin has been found in eukaryotic-interacting bacteria and probably inhibits host proteases (Budd et al., 2004). In contrast, Tex-like proteins are involved in toxin expression in some pathogens (Johnson et al., 2008). In addition to host interactions, RHS proteins mediate intracellular competition (Koskiniemi et al., 2013; Nikaido and Takatsuka, 2009), while beta-lactamases and RND efflux transporters promote antibiotic resistance. Other genes relevant to plant-bacteria interactions identified in the squash root metagenome were TonB receptors for 
iron siderophores and iron-chelating molecules that may drive bacteria-bacteria interactions (Kramer et al., 2020). Additionally, TonB-dependent receptors may be involved in plant carbohydrate assimilation (Blanvillain et al., 2007).

Further work will test the expression profiles of some genes mentioned here. We were cautious about metatranscriptomics approaches because of the less than 6.8 minutes as the half-life average for mRNAs operons under controlled conditions and single-species experiments (Selinger et al., 2003), having a complete profile with biological meaning would need sequencing depths out of the scope of this work. The significant differences between the arid and humid metagenomes are encouraging because of the selective pressure in bacterial genomes for size reduction (Mira et al., 2006; Pushker et al., 2004). Bacterial genome reduction is correlated with accelerated evolution (Dufresne et al., 2005), growth (Kurokawa et al., 2016), and some of the lost genes being beneficial in selected conditions but deleterious in alternative environments (Lee and Marx, 2012), suggesting that the differences in gene content could be adaptive for the tested conditions. We did not test genome reductions, but the same plants under contrasting conditions host differential taxa and genes, encouraging the microbiomes as diversity and genetic repositories for local adaptation.

\section{Conclusions}

Our experimental design allowed us to collect the in situ soil diversity, use it as a small inoculant for a common garden experiment while conserving their source traits. We identified the shared and differential root-associated bacteria taxa and genes in samples derived from arid and humid environments. Conserving the soil microbiota differences from humid and arid sites maintained in environmental samples and the common garden experiment was remarkable. This ex-situ microbiome conservation is especially notable since treatments involving soil inoculum consisted of a small fraction of substrates. Coupled with taxonomic differentiation, we detected coding genes associated with adaptations to arid environments. We described bacteria and genes relevant to plants' interaction and promoting their growth while providing a pool of metabolic abilities for coping with hydric stress. 


\section{Declaration of competing interest}

The authors declare no competing interests.

\section{Acknowledgments}

This work was supported by the Consejo Nacional de Ciencia y Tecnología (Conacyt) Problemas Nacionales 247730 to DP. Conacyt Ciencia Básica 237387 and Universidad Nacional Autónoma de México DGAPA-PAPIIT UNAM IN221420 to LDA. Conacyt Ph.D. scholarship (CVU 742786) to CHA. Soil physicochemical analyses were carried out by Rodrigo Velázquez Durán. We appreciate field work assistance by Shamayim Martínez-Sánchez. Some analyses were carried out using CONABIO's computing cluster, which was partially funded by SEMARNAT through the grant Contribución de la Biodiversidad para el Cambio Climático with support from Alicia Mastretta-Yañez and Ernesto Campos. This paper is part of the doctoral thesis of $\mathrm{CHA}$ and is a requirement for obtaining a Ph.D. from the Posgrado en Ciencias Biológicas, Universidad Nacional Autónoma de México (UNAM). We thank the kind comments and suggestions of the reviewers that improved the manuscript. 


\section{References}

Aizawa, S.-I., 2014. Pectobacterium carotovorum - Subpolar Hyper-Flagellation, in: The Flagellar World. Academic Press, pp. 58-59. https://doi.org/10.1016/b978-0-12-417234-0.00018-9

Alcaraz, L.D., Peimbert, M., Barajas, H.R., Dorantes-Acosta, A.E., Bowman, J.L., Arteaga-Vázquez, M.A., 2018. Marchantia liverworts as a proxy to plants' basal microbiomes. Scientific Reports 8, 1-12. https://doi.org/10.1038/s41598-018-31168-0

Alsharif, W., Saad, M.M., Hirt, H., 2020. Desert Microbes for Boosting Sustainable Agriculture in Extreme Environments. Frontiers in Microbiology 11:1666. https://doi.org/10.3389/fmicb.2020.01666

Altschul, S.F., Gish, W., Miller, W., Myers, E.W., Lipman, D.J., 1990. Basic local alignment search tool. Journal of Molecular Biology 215(3), 403-410. https://doi.org/10.1016/S0022-2836(05)80360-2

Anderson, M., Habiger, J., 2012. Characterization and identification of productivity-associated rhizobacteria in wheat. Applied and Environmental Microbiology 78(12), 4434-4446. https://doi.org/10.1128/AEM.07466-11

Anderson, M.J., Willis, T.J., 2003. Canonical analysis of principal coordinates: A useful method of constrained ordination for ecology. Ecology 84(2), 511-525. https://doi.org/10.1890/0012-9658(2003)084[0511:CAOPCA]2.0.CO;2

Asadi Zarch, M.A., Sivakumar, B., Malekinezhad, H., Sharma, A., 2017. Future aridity under conditions of global climate change. Journal of Hydrology 554, 451-469. https://doi.org/10.1016/j.jhydrol.2017.08.043

Aslam, Z., Park, J.H., Kim, S.W., Jeon, C.O., Chung, Y.R., 2009. Arenimonas oryziterrae sp. nov., isolated from a field of rice (Oryza sativa L.) managed under a notillage regime, and reclassification of Aspromonas composti as Arenimonas composti comb. nov. International Journal of Systematic and Evolutionary Microbiology 59(12), 2967-2972. https://doi.org/10.1099/ijs.0.006031-0

Bach, J.N., Bramkamp, M., 2015. Dissecting the molecular properties of prokaryotic flotillins. PLoS ONE 10(1), e0116750. https://doi.org/10.1371/journal.pone.0116750 
Barajas, H., Martínez-Sánchez, S., Romero, M., Hernández-Álvarez, C., Servín-González, L., Peimbert, M., Cruz-Ortega, R., García-Oliva, F., Alcaraz, L., 2020. Testing the two-step model of plant root microbiome acquisition under multiple plant species and soil sources. Frontiers in microbiology 11: 542742. https://doi.org/10.1101/2020.03.11.988014

Blanvillain, S., Meyer, D., Boulanger, A., Lautier, M., Guynet, C., Denancé, N., Vasse, J., Lauber, E., Arlat, M., 2007. Plant carbohydrate scavenging through TonB-dependent receptors: A feature shared by phytopathogenic and aquatic bacteria. PLoS One, 2(2), e224. https://doi.org/10.1371/journal.pone.0000224

Breinig, S., Schiltz, E., Fuchs, G., 2000. Genes involved in anaerobic metabolism of phenol in the bacterium Thauera aromatica. J. Bacteriol, 182(20), 5849-5863. https://doi.org/10.1128/JB.182.20.5849-5863.2000

Bolger, A.M., Lohse, M., Usadel, B., 2014. Trimmomatic: A flexible trimmer for Illumina $\begin{array}{llll}\text { sequence } \quad \text { data. } & \text { 30(15), }\end{array}$ https://doi.org/10.1093/bioinformatics/btu170

Bremner, J., Mulvaney, C., 1982. Nitrogen - Total, in: Page, A.L., Miller, R.H. and K. (Ed.), Methods of Soil Analysis. Part 2. Chemical and Microbiological Properties. American Society of Agronomy, Soil Science Society of America, Madison, Wisconsin, pp. 595-624. https://doi.org/https://doi.org/10.2134/agronmonogr9.2.2ed.c31

Buchfink, B., Xie, C., Huson, D.H., 2014. Fast and sensitive protein alignment using DIAMOND. Nature Methods 12(1), 59-60. https://doi.org/10.1038/nmeth.3176

Budd, A., Blandin, S., Levashina, E.A., Gibson, T.J., 2004. Bacterial a 2-macroglobulins: colonization factors acquired by horizontal gene transfer from the metazoan genome? Genome biology 5(6), 1-13. https://doi.org/10.1186/gb-2004-5-6-r38

Bulgarelli, D., Rott, M., Schlaeppi, K., Ver Loren van Themaat, E., Ahmadinejad, N., Assenza, F., Rauf, P., Huettel, B., Reinhardt, R., Schmelzer, E., Peplies, J., Gloeckner, F.O., Amann, R., Eickhorst, T., Schulze-Lefert, P., 2012. Revealing structure and assembly cues for Arabidopsis root-inhabiting bacterial microbiota. Nature 488(7409), 91-95. https://doi.org/10.1038/nature11336 
Bulgarelli, D., Schlaeppi, K., Spaepen, S., van Themaat, E.V.L., Schulze-Lefert, P., 2013. Structure and Functions of the Bacterial Microbiota of Plants. Annual Review of Plant Biology 64, 807-838. https://doi.org/10.1146/annurev-arplant-050312-120106

Caporaso, J.G., Kuczynski, J., Stombaugh, J., Bittinger, K., Bushman, F.D., Costello, E.K., Fierer, N., Pẽa, A.G., Goodrich, J.K., Gordon, J.I., Huttley, G.A., Kelley, S.T., Knights, D., Koenig, J.E., Ley, R.E., Lozupone, C.A., McDonald, D., Muegge, B.D., Pirrung, M., Reeder, J., Sevinsky, J.R., Turnbaugh, P.J., Walters, W.A., Widmann, J., Yatsunenko, T., Zaneveld, J., Knight, R., 2010. QIIME allows analysis of high-throughput community sequencing data. Nature Methods 7(5), 335-336. https://doi.org/10.1038/nmeth.f.303

Chen, X., Miché, L., Sachs, S., Wang, Q., Buschart, A., Yang, H., Vera Cruz, C.M., Hurek, T., Reinhold-Hurek, B., 2015. Rice responds to endophytic colonization which is independent of the common symbiotic signaling pathway. New Phytologist 208(2), 531-543. https://doi.org/10.1111/nph.13458

Collins, T., Gerday, C., Feller, G., 2005. Xylanases, xylanase families and extremophilic xylanases. FEMS Microbiology Reviews 29(1), 3-23.. https://doi.org/10.1016/j.femsre.2004.06.005

Comeau, D., Novinscak, A., Joly, D.L., Filion, M., 2020. Spatio-Temporal and Cultivar-Dependent Variations in the Cannabis Microbiome. Frontiers in Microbiology 11, 491. https://doi.org/10.3389/fmicb.2020.00491

CONABIO, 2018. Geoportal del Sistema Nacional de Información sobre Biodiversidad http://www.conabio.gob.mx/informacion/gis/

Czech, L., Hermann, L., Stöveken, N., Richter, A.A., Höppner, A., Smits, S.H.J., Heider, J., Bremer, E., 2018. Role of the extremolytes ectoine and hydroxyectoine as stress protectants and nutrients: Genetics, phylogenomics, biochemistry, and structural analysis. Genes 9(4), 177. https://doi.org/10.3390/genes9040177

Dai, A., 2013. Increasing drought under global warming in observations and models. Nature Climate Change 3(1), 52-58. https://doi.org/10.1038/nclimate1633

De Wulf, P., McGuire, A.M., Liu, X., Lin, E.C.C., 2002. Genome-wide profiling of promoter recognition by the two-component response regulator CpxR-P in Escherichia coli. 
Journal of Biological Chemistry 277(29), 26652-26661. https://doi.org/10.1074/jbc.M203487200

de Villemereuil, P., Gaggiotti, O. E., Mouterde, M., Till-Bottraud, I., 2016. Common garden experiments in the genomic era: new perspectives and opportunities. Heredity, 116(3), 249-254. https://doi.org/10.1038/hdy.2015.93

Delgado-Baquerizo, M., Oliverio, A.M., Brewer, T.E., Benavent-González, A., Eldridge, D.J., Bardgett, R.D., Maestre, F.T., Singh, B.K., Fierer, N., 2018. A global atlas of the dominant bacteria found in soil. Science 359(6373), 320-325. https://doi.org/10.1126/science.aap9516

Du, Z.J., Wang, Z.J., Zhao, J.X., Chen, G.J., 2016. Woeseia oceani gen. Nov., sp. nov., a chemoheterotrophic member of the order Chromatiales, and proposal of Woeseiaceae fam. nov. International Journal of Systematic and Evolutionary Microbiology 66(1), 107-112. https://doi.org/10.1099/ijsem.0.000683

Dufresne, A., Garczarek, L., \& Partensky, F., 2005. Accelerated evolution associated with genome reduction in a free-living prokaryote. Genome biology, 6(2), 1-10. https://dx.doi.org/10.1186\%2Fgb-2005-6-2-r14

Eguiarte, L.E., Hernández-Rosales, H.S., Barrera-Redondo, J., Castellanos-Morales, G., Paredes-Torres, L.M., Sánchez-de la Vega, G., Ruiz-Mondragón, K.Y., Vázquez-Lobo, A., Montes-Hernández, S., Aguirre-Planter, E., Souza, V., Lira, R., 2018. Domesticación, diversidad y recursos genéticos y genómicos de México: El caso de las calabazas. TIP Revista Especializada en Ciencias Químico-Biológicas 21, 85-101. https://doi.org/10.22201/fesz.23958723e.2018.0.159

Ettema, C.H., Wardle, D.A., 2002. Spatial soil ecology. Trends in Ecology and Evolution 17(4), 177-183. https://doi.org/10.1016/S0169-5347(02)02496-5

Fernández Eguiarte, A., Romero Centeno, R., Zavala Hidalgo, J., 2014. Methodologies used in the digital climatic atlas of Mexico for generating high-resolution maps. Geoacta 39(1), 165-173.

Fierer, N., Leff, J.W., Adams, B.J., Nielsen, U.N., Bates, S.T., Lauber, C.L., Owens, S., Gilbert, J.A., Wall, D.H., Caporaso, J.G., 2012. Cross-biome metagenomic analyses of soil microbial communities and their functional attributes. Proceedings of the National 
Academy of Sciences of the United States of America 109(52), 21390-21395. https://doi.org/10.1073/pnas.1215210110

Fitzpatrick, C.R., Copeland, J., Wang, P.W., Guttman, D.S., Kotanen, P.M., Johnson, M.T.J., 2018. Assembly and ecological function of the root microbiome across angiosperm plant species. Proceedings of the National Academy of Sciences of the United States of America 115(6), E1157-E1165. https://doi.org/10.1073/pnas.1717617115

Gordon, A., Hannon, G.J., 2010. Fastx-toolkit. FASTQ/A short-reads pre-processing tools. Unpublished http://hannonlab. cshl. edu/fastx_toolkit.

Herlemann, D.P.R., Labrenz, M., Jürgens, K., Bertilsson, S., Waniek, J.J., Andersson, A.F., 2011. Transitions in bacterial communities along the $2000 \mathrm{~km}$ salinity gradient of the Baltic Sea. ISME Journal 5(10), 1571-1579. https://doi.org/10.1038/ismej.2011.41

Hernández, A.M., Vargas-Robles, D., Alcaraz, L.D., Peimbert, M., 2020. Station and train surface microbiomes of Mexico City's metro (subway/underground). Scientific Reports 10(1), 1-10. https://doi.org/10.1038/s41598-020-65643-4

Heulin, T., De Luca, G., Barakat, M., Gommeaux, M., de Groot, A., Blanchard, L., Ortet, P., Achouak, W., 2017. Bacterial adaptation to hot and dry deserts, in: Stan-Lotter, Helga, Fendrihan, S. (Ed.), Adaption of Microbial Life to Environmental Extremes: Novel Research Results and Application. Springer, Cham, pp. 75-98. https://doi.org/10.1007/978-3-319-48327-6_4

Hubber, A., Vergunst, A.C., Sullivan, J.T., Hooykaas, P.J.J., Ronson, C.W., 2004. Symbiotic phenotypes and translocated effector proteins of the Mesorhizobium loti strain R7A VirB/D4 type IV secretion system. Molecular Microbiology 54(2), 561-574. https://doi.org/10.1111/j.1365-2958.2004.04292.

Huffman, E.W.D., 1977. Performance of a new automatic carbon dioxide coulometer. Microchemical Journal 22(4), 567-573. https://doi.org/10.1016/0026-265X(77)90128-X

Hyatt, D., Chen, G.L., LoCascio, P.F., Land, M.L., Larimer, F.W., Hauser, L.J., 2010. Prodigal: Prokaryotic gene recognition and translation initiation site identification. BMC Bioinformatics 11(1), 1-11. https://doi.org/10.1186/1471-2105-11-119 
Illumina Inc., 2013. 16S Metagenomic Sequencing Library Preparation - Preparing 16S Ribosomal RNA Gene Amplicons for the Illumina MiSeq System. 16S Metagenomic Sequencing Library Preparation Manual.

Johnson, S.J., Close, D., Robinson, H., Vallet-Gely, I., Dove, S.L., Hill, CP, 2008. Crystal Structure and RNA Binding of the Tex Protein from Pseudomonas aeruginosa. Journal of Molecular Biology 377(5), 1460-1473. https://doi.org/10.1016/j.jmb.2008.01.096

Jones, P., Garcia, B.J., Furches, A., Tuskan, G.A., Jacobson, D., 2019. Plant host-associated mechanisms for microbial selection. Frontiers in Plant Science 10, 862. https://doi.org/10.3389/fpls.2019.00862

Kaiser, K., Wemheuer, B., Korolkow, V., Wemheuer, F., Nacke, H., Schöning, I., Schrumpf, M., Daniel, R., 2016. Driving forces of soil bacterial community structure, diversity, and function in temperate grasslands and forests. Scientific Reports 6(1), 1-12. https://doi.org/10.1038/srep33696

Kanehisa, M., Goto, S., 2000. KEGG: Kyoto encyclopedia of genes and genomes. Nucleic acids research, 28 (1), 27-30. https://doi.org/10.1093/nar/28.1.27

Kanehisa, M., Sato, Y., 2020. KEGG Mapper for inferring cellular functions from protein sequences. Protein Science 29(1), 28-35. https://doi.org/10.1002/pro.3711

Kanjanasuntree, R., Kim, J.H., Yoon, J.H., Sukhoom, A., Kantachote, D., Kim, W., 2018. Arenimonas halophila sp. Nov., isolated from soil. International Journal of Systematic and Evolutionary $\quad$ Microbiology 68(7), 2188-2193. https://doi.org/10.1099/ijsem.0.002801

Koskiniemi, S., Lamoureux, J.G., Nikolakakis, K.C., De Roodenbeke, C.T.K., Kaplan, M.D., Low, D.A., Hayes, C.S., 2013. Rhs proteins from diverse bacteria mediate intercellular competition. Proceedings of the National Academy of Sciences of the $\begin{array}{llll}\text { United States } & \text { of }\end{array}$ https://doi.org/10.1073/pnas.1300627110

Kramer, J., Özkaya, Ö., Kümmerli, R., 2020. Bacterial siderophores in community and host interactions. Nature Reviews Microbiology 18(3), 152-163. https://doi.org/10.1038/s41579-019-0284-4 
Kurokawa, M., Seno, S., Matsuda, H., \& Ying, B. W., 2016. Correlation between genome reduction and bacterial growth. DNA research, 23(6), 517-525. https://doi.org/10.1093/dnares/dsw035

Kutschera, U., 2007. Plant-associated methylobacteria as co-evolved phytosymbionts: A hypothesis. Plant Signaling and Behavior 2(2), 74-78. https://doi.org/10.4161/psb.2.2.4073

Langmead, B., Salzberg, S.L., 2012. Fast gapped-read alignment with Bowtie 2. Nature Methods 9(4), 357. https://doi.org/10.1038/nmeth.1923

Lauber, C.L., Hamady, M., Knight, R., Fierer, N., 2009. Pyrosequencing-based assessment of soil $\mathrm{pH}$ as a predictor of soil bacterial community structure at the continental scale. Applied and Environmental Microbiology 75(15), 5111-5120. https://doi.org/10.1128/AEM.00335-09

Lebre, P.H., De Maayer, P., Cowan, D.A., 2017. Xerotolerant bacteria: Surviving through a dry spell. Nature Reviews Microbiology 15(5), 285-296. https://doi.org/10.1038/nrmicro.2017.16

Lee, M. C., \& Marx, C. J., 2012. Repeated, selection-driven genome reduction of accessory genes in experimental populations. PLoS genetics, 8(5), e1002651. https://doi.org/10.1371/journal.pgen.1002651

Levy, A., Conway, J.M., Dangl, J.L., Woyke, T., 2018. Elucidating Bacterial Gene Functions in the Plant Microbiome. Cell Host and Microbe 24(4), 475-485. https://doi.org/10.1016/j.chom.2018.09.005

Lewandowska, M., Jarvis, P.G., 1977. Changes in chlorophyll and carotenoid content, specific leaf area and dry weight fraction in Sitka spruce, in response to shading and season. New Phytologist 79, 247-256. https://doi.org/10.1111/j.1469-8137.1977.tb02202.x

Li, D., Rothballer, M., Engel, M., Hoser, J., Schmidt, T., Kuttler, C., Schmid, M., Schloter, M., Hartmann, A., 2012. Phenotypic variation in Acidovorax radicis N35 influences plant growth promotion. FEMS Microbiology Ecology 79(3), 751-762. https://doi.org/10.1111/j.1574-6941.2011.01259.x 
Li, H., Handsaker, B., Wysoker, A., Fennell, T., Ruan, J., Homer, N., Marth, G., Abecasis, G., Durbin, R., 2009. The Sequence Alignment/Map format and SAMtools. Bioinformatics 25(16), 2078-2079. https://doi.org/10.1093/bioinformatics/btp352

Li, W., Godzik, A., 2006. Cd-hit: A fast program for clustering and comparing large sets of protein or nucleotide sequences. Bioinformatics 22(13), 1658-1659. https://doi.org/10.1093/bioinformatics/btl158

Li, W.J., Chen, H.H., Xu, P., Zhang, Y.Q., Schumann, P., Tang, S.K., Xu, L.H., Jiang, C.L., 2004. Yania halotolerans gen nov., sp. nov., a novel member of the suborder Micrococcineae from saline soil in China. International Journal of Systematic and Evolutionary Microbiology 54(2), 525-531. https://doi.org/10.1099/ijs.0.02875-0

Li, Y., Wu, X., Chen, T., Wang, W., Liu, G., Zhang, W., Li, S., Wang, M., Zhao, C., Zhou, H., Zhang, G., 2018. Plant phenotypic traits eventually shape its microbiota: A common $\begin{array}{llllll}\text { garden test. Frontiers in Microbiology } & 9479 .\end{array}$ https://doi.org/10.3389/fmicb.2018.02479

Lin, T.Y., Weibel, D.B., 2016. Organization and function of anionic phospholipids in bacteria. Applied Microbiology and Biotechnology 100(10), 4255-4267. https://doi.org/10.1007/s00253-016-7468-x

Ling, N., Chen, D., Guo, H., Wei, J., Bai, Y., Shen, Q., Hu, S., 2017. Differential responses of soil bacterial communities to long-term $\mathrm{N}$ and $\mathrm{P}$ inputs in a semi-arid steppe. Geoderma 292, 25-33. https://doi.org/10.1016/j.geoderma.2017.01.013

Love, M.I., Huber, W., Anders, S., 2014. Moderated estimation of fold change and dispersion for RNA-seq data with DESeq2. Genome Biology 15(12), 1-21. https://doi.org/10.1186/s13059-014-0550-8

Lozupone, C., Lladser, M.E., Knights, D., Stombaugh, J., Knight, R., 2011. UniFrac: An effective distance metric for microbial community comparison. ISME Journal 5(2), 169-172.. https://doi.org/10.1038/ismej.2010.133

Lundberg, D., Lebeis, S., Paredes, S., Yourstone, S., Gehring, J., Malfatti, S., Tremblay, J., Engelbrektson, A., Kunin, V., Engelbrektson, A., Kunin, V., Glavina del Rio, T., Hugenholtz, P., Tringe, S.G., 2012. Defining the core Arabidopsis thaliana root microbiome. Nature 488(7409), 85-90. https://doi.org/10.1038/nature11237 
Marçais, G., Delcher, A.L., Phillippy, A.M., Coston, R., Salzberg, S.L., Zimin, A., 2018. MUMmer4: A fast and versatile genome alignment system. PLoS Computational Biology 14(1), e1005944. https://doi.org/10.1371/journal.pcbi.1005944

Masella, A.P., Bartram, A.K., Truszkowski, J.M., Brown, D.G., Neufeld, J.D., 2012. PANDAseq: Paired-end assembler for Illumina sequences. BMC Bioinformatics 13(1), 1-7. https://doi.org/10.1186/1471-2105-13-31

McMurdie, P.J., Holmes, S., 2013. Phyloseq: An R Package for Reproducible Interactive Analysis and Graphics of Microbiome Census Data. PLoS ONE 8(4), e61217. https://doi.org/10.1371/journal.pone.0061217

Mira, A., Pushker, R., \& Rodriguez-Valera, F., 2006. The Neolithic revolution of bacterial genomes. Trends in microbiology, 14(5), 200-206. https://doi.org/10.1016/j.tim.2006.03.001

Montero-Pau, J., Blanca, J., Bombarely, A., Ziarsolo, P., Esteras, C., Martí-Gómez, C., Ferriol, M., Gómez, P., Jamilena, M., Mueller, L., Picó, B., Cañizares, J., 2018. De novo assembly of the zucchini genome reveals a whole-genome duplication associated with the origin of the Cucurbita genus. Plant Biotechnology Journal 16(6), 1161-1171. https://doi.org/10.1111/pbi.12860

Müller, D.B., Vogel, C., Bai, Y., Vorholt, J.A., 2016. The Plant Microbiota: Systems-Level Insights and Perspectives. Annual Review of Genetics 50, 211-234. https://doi.org/10.1146/annurev-genet-120215-034952

Murakami, M., Shibuya, K., Nakayama, T., Nishino, T., Yoshimura, T., Hemmi, H., 2007. Geranylgeranyl reductase involved in the biosynthesis of archaeal membrane lipids in the hyperthermophilic archaeon Archaeoglobus fulgidus. FEBS Journal 274(3), 805-814. https://doi.org/10.1111/j.1742-4658.2006.05625.x

Murphy, J., Riley, J.P., 1962. A modified single solution method for the determination of phosphate in natural waters. Analytica Chimica Acta 27, 31-36. https://doi.org/10.1016/S0003-2670(00)88444-5

Nagasawa, S., Ishige, K., Mizuno, T., 1993. Novel members of the two-component signal transduction genes in Escherichia coli. Journal of Biochemistry 114(3), 350-357. https://doi.org/10.1093/oxfordjournals.jbchem.a124180 
Naylor, D., Coleman-Derr, D., 2018. Drought stress and root-associated bacterial communities. Frontiers in Plant Science 8,2223. https://doi.org/10.3389/fpls.2017.02223

Naylor, D., Degraaf, S., Purdom, E., Coleman-Derr, D., 2017. Drought and host selection influence bacterial community dynamics in the grass-root microbiome. ISME Journal 11(12), 2691-2704. https://doi.org/10.1038/ismej.2017.118

Nedashkovskaya, O.I., Vancanneyt, M., Kim, S.B., Han, J., Zhukova, N. V., Shevchenko, L.S., 2010. Salinimicrobium marinum sp. nov., a halophilic bacterium of the family Flavobacteriaceae, and emended descriptions of the genus Salinimicrobium and Salinimicrobium catena. International Journal of Systematic and Evolutionary Microbiology 60(10), 2303-2306. https://doi.org/10.1099/ijs.0.019166-0

Neilson, J.W., Califf, K., Cardona, C., Copeland, A., van Treuren, W., Josephson, K.L., Knight, R., Gilbert, J.A., Quade, J., Caporaso, J.G., Maier, R.M., 2017. Significant Impacts of Increasing Aridity on the Arid Soil Microbiome. mSystems 2(3), e00195-16. https://doi.org/10.1128/msystems.00195-16

Newton, G.L., Buchmeier, N., Fahey, R.C., 2008. Biosynthesis and Functions of Mycothiol, the Unique Protective Thiol of Actinobacteria. Microbiology and Molecular Biology Reviews 72(3), 471-497. https://doi.org/10.1128/mmbr.00008-08

Nikaido, H., Takatsuka, Y., 2009. Mechanisms of RND multidrug efflux pumps. Biochimica et Biophysica Acta (BBA) - Proteins and Proteomics 1794(5), 769-781. https://doi.org/10.1016/j.bbapap.2008.10.004

Nurk, S., Meleshko, D., Korobeynikov, A., Pevzner, P.A., 2017. MetaSPAdes: A new versatile metagenomic assembler. Genome Research 27, 824-834. https://doi.org/10.1101/gr.213959.116

O'Leary, N.A., Wright, M.W., Brister, J.R., Ciufo, S., Haddad, D., McVeigh, R., Rajput, B., Robbertse, B., Smith-White, B., Ako-Adjei, D., Astashyn, A., Badretdin, A., Bao, Y., Blinkova, O., Brover, V., Chetvernin, V., Choi, J., Cox, E., Ermolaeva, O., Farrell, C.M., Goldfarb, T., Gupta, T., Haft, D., Hatcher, E., Hlavina, W., Joardar, V.S., Kodali, V.K., Li, W., Maglott, D., Masterson, P., McGarvey, K.M., Murphy, M.R., O’Neill, K., Pujar, S., Rangwala, S.H., Rausch, D., Riddick, L.D., Schoch, C., Shkeda, A., Storz, 
S.S., Sun, H., Thibaud-Nissen, F., Tolstoy, I., Tully, R.E., Vatsan, A.R., Wallin, C., Webb, D., Wu, W., Landrum, M.J., Kimchi, A., Tatusova, T., DiCuccio, M., Kitts, P., Murphy, T.D., Pruitt, K.D., 2016. Reference sequence (RefSeq) database at NCBI: Current status, taxonomic expansion, and functional annotation. Nucleic Acids Research 44(D1), D733-D745. https://doi.org/10.1093/nar/gkv1189

Oksanen, J., Blanchet, F.G., Friendly, M., Kindt, R., Legendre, P., McGlinn, D., Minchin, P.R., O'Hara, R.B., Simpson, G.L., Solymos, P., Stevens, M.H.H., Szoecs, E., Wagner, H., 2019. Vegan: community ecology package. Ordination methods, diversity analysis and other functions for community and vegetation ecologists. R package ver, 2-3. Cran R.

Overbeek, R., Begley, T., Butler, R.M., Choudhuri, J. V., Chuang, H.Y., Cohoon, M., de Crécy-Lagard, V., Diaz, N., Disz, T., Edwards, R., Fonstein, M., Frank, E.D., Gerdes, S., Glass, E.M., Goesmann, A., Hanson, A., Iwata-Reuyl, D., Jensen, R., Jamshidi, N., Krause, L., Kubal, M., Larsen, N., Linke, B., McHardy, A.C., Meyer, F., Neuweger, H., Olsen, G., Olson, R., Osterman, A., Portnoy, V., Pusch, G.D., Rodionov, D.A., Rül;ckert, C., Steiner, J., Stevens, R., Thiele, I., Vassieva, O., Ye, Y., Zagnitko, O., Vonstein, V., 2005. The subsystems approach to genome annotation and its use in the project to annotate 1000 genomes. Nucleic Acids Research 33(17), 5691-5702. https://doi.org/10.1093/nar/gki866

Oves, M., Khan, M.S., Qari, HA, 2017. Ensifer adhaerens for heavy metal bioaccumulation, biosorption, and phosphate solubilization under metal stress conditions. Journal of the Taiwan Institute of Chemical Engineers 80, 540-552. https://doi.org/10.1016/j.jtice.2017.08.026

Partida-Martínez, L.P., Heil, M., 2011. The microbe-free plant: Fact or artifact? Frontiers in Plant Science 2, 1-16. https://doi.org/10.3389/fpls.2011.00100

Peralta, R.M., Ahn, C., Gillevet, P.M., 2013. Characterization of soil bacterial community structure and physicochemical properties in created and natural wetlands. Science of the Total Environment 443, 725-732. https://doi.org/10.1016/j.scitotenv.2012.11.052

Porter, J.R., Xie, L., Challinor, A.J., Cochrane, K., Howden, S.M., Iqbal, M.M., Lobell, D.B., Travasso, M.I., Aggarwal, P., Hakala, K., Jordan, J., 2014. Food security and food 
production systems, in: Climate Change 2014 Impacts, Adaptation and Vulnerability: Part A: Global and Sectoral Aspects. Press, Cambridge University, pp. 485-533. https://doi.org/10.1017/CBO9781107415379.012

Pushker, R., Mira, A., \& Rodríguez-Valera, F., 2004. Comparative genomics of gene-family size in closely related bacteria. Genome biology, 5(4), 1-15. https://doi.org/10.1186/gb-2004-5-4-r27

Quan, C., Han, S., Utescher, T., Zhang, C., Liu, Y.S.C., 2013. Validation of temperature-precipitation based aridity index: Paleoclimatic implications. $\begin{array}{llll}\text { Palaeogeogr. } & \text { Palaeoclimatol. } & \text { 86-95. }\end{array}$ https://doi.org/10.1016/j.palaeo.2013.05.008

Quast, C., Pruesse, E., Yilmaz, P., Gerken, J., Schweer, T., Yarza, P., Peplies, J., Glöckner, F.O., 2013. The SILVA ribosomal RNA gene database project: Improved data processing and web-based tools. Nucleic Acids Research 41(D1), D590-D596. https://doi.org/10.1093/nar/gks1219

R Development Core Team, R., 2011. R: A Language and Environment for Statistical Computing. $\mathrm{R}$ Foundation for Statistical Computing. https://doi.org/10.1007/978-3-540-74686-7

Rangjaroen, C., Sungthong, R., Rerkasem, B., Teaumroong, N., Noisangiam, R., Lumyong, S., 2017. Untapped endophytic colonization and plant growth-promoting potential of the genus Novosphingobium to optimize rice cultivation. Microbes and Environments 32(1), 84-87. https://doi.org/10.1264/jsme2.ME16112

Reed, H. E., Martiny, J. B., 2007. Testing the functional significance of microbial composition in natural communities. FEMS microbiology ecology, 62(2), 161-170. https://doi.org/10.1111/j.1574-6941.2007.00386.x

Reinhold-Hurek, B., Hurek, T., Gillis, M., Hoste, B., Vancanneyt, M., Kersters, K., De Ley, J., 1993. Azoarcus gen. nov., nitrogen-fixing Proteobacteria associated with roots of Kallar grass (Leptochloa fusca (L.) Kunth), and description of two species, Azoarcus indigens sp. nov. and Azoarcus communis sp. nov. International Journal of Systematic Bacteriology 43(3), 574-584. https://doi.org/10.1099/00207713-43-3-574 Revelle, M.W., 2017. psych: Procedures for personality and psychological research. 
Romero, M.F., Gallego, D., Lechuga-Jiménez, A., Martínez, J.F., Barajas, H.R., Hayano-Kanashiro, C., Peimbert, M., Cruz-Ortega, R., Molina-Freaner, F.E., Alcaraz, L.D., 2021. Metagenomics of mine tailing rhizospheric communities and its selection for plant establishment towards bioremediation. Microbiological Research 126732. https://doi.org/10.1016/j.micres.2021.126732

Rosenzweig, C., Elliott, J., Deryng, D., Ruane, A.C., Müller, C., Arneth, A., Boote, K.J., Folberth, C., Glotter, M., Khabarov, N., Neumann, K., Piontek, F., Pugh, T.A.M., Schmid, E., Stehfest, E., Yang, H., Jones, J.W., 2014. Assessing agricultural risks of climate change in the 21st century in a global gridded crop model intercomparison. Proceedings of the National Academy of Sciences of the United States of America 111(9), 3268-3273. https://doi.org/10.1073/pnas.1222463110

Santos-Medellín, C., Edwards, J., Liechty, Z., Nguyen, B., Sundaresan, V., 2017. Drought stress results in a compartment-specific restructuring of the rice root-associated microbiomes. mBio 8(4), e00764-17. https://doi.org/10.1128/mBio.00764-17

Sasse, J., Martinoia, E., Northen, T., 2018. Feed Your Friends: Do Plant Exudates Shape the Root Microbiome?. Trends in Plant Science 23(1), 25-41. https://doi.org/10.1016/j.tplants.2017.09.003

Schneider, C.A., Rasband, W.S., Eliceiri, K.W., 2012. NIH Image to ImageJ: 25 years of image analysis. Nature Methods 9(7), 671-675. https://doi.org/10.1038/nmeth.2089

Selinger, D. W., Saxena, R. M., Cheung, K. J., Church, G. M., \& Rosenow, C., 2003. Global RNA half-life analysis in Escherichia coli reveals positional patterns of transcript degradation. Genome research, 13(2), 216-223. http://www.genome.org/cgi/doi/10.1101/gr.912603

Shirakura, Y., Fukui, T., Tanio, T., Nakayama, K., Matsuno, R., Tomita, K., 1983. An extracellular d(-)-3-hydroxybutyrate oligomer hydrolase from Alcaligenes faecalis. Biochimica et Biophysica Acta (BBA) - Protein Structure and Molecular 748(2), 331-339. https://doi.org/10.1016/0167-4838(83)90310-2

Smirnova, G. V., Oktyabrsky, O.N., 2005. Glutathione in bacteria. Biochemistry (Moscow) 70(11), 1126-1129. https://doi.org/10.1007/s10541-005-0248-3 
Sousa, J.A. de J., Olivares, F.L., 2016. Plant growth promotion by streptomycetes: Ecophysiology, mechanisms and applications. Chemical and Biological Technologies in Agriculture 3, 1-12. https://doi.org/10.1186/s40538-016-0073-5

Soussi, A., Ferjani, R., Marasco, R., Guesmi, A., Cherif, H., Rolli, E., Mapelli, F., Ouzari, H.I., Daffonchio, D., Cherif, A., 2016. Plant-associated microbiomes in arid lands: diversity, ecology and biotechnological potential. Plant and Soil 405, 357-370. https://doi.org/10.1007/s11104-015-2650-y

Suarez, C., Ratering, S., Kramer, I., Schnell, S., 2014. Cellvibrio diazotrophicus sp. nov., a nitrogen-fixing bacteria isolated from the rhizosphere of salt meadow plants and emended description of the genus Cellvibrio. International Journal of Systematic and Evolutionary Microbiology 64, 481-486. https://doi.org/10.1099/ijs.0.054817-0

Sudhakar, P., Latha, P., Reddy, P. V, 2016. Plant pigments, in: P. Sudhakar, P. Latha, PVR (Ed.), Phenotyping Crop Plants for Physiological and Biochemical Traits. Academic Press, pp.

$121-127$. https://doi.org/https://doi.org/10.1016/B978-0-12-804073-7.00015-6

Tripathi, B.M., Stegen, J.C., Kim, M., Dong, K., Adams, J.M., Lee, Y.K., 2018. Soil pH mediates the balance between stochastic and deterministic assembly of bacteria. ISME Journal 12, 1072-1083. https://doi.org/10.1038/s41396-018-0082-4

Uroz, S., loannidis, P., Lengelle, J., Cébron, A., Morin, E., Buée, M., Martin, F., 2013. Functional Assays and Metagenomic Analyses Reveals Differences between the Microbial Communities Inhabiting the Soil Horizons of a Norway Spruce Plantation. PLoS ONE 8(2), e55929. https://doi.org/10.1371/journal.pone.0055929

Vannier, N., Mony, C., Bittebière, A.K., Vandenkoornhuyse, P., 2015. Epigenetic mechanisms and microbiota as a toolbox for plant phenotypic adjustment to environment. Front. Plant Sci. 6, 1159. https://doi.org/10.3389/fpls.2015.01159

Walsh, N.P., Alba, B.M., Bose, B., Gross, C.A., Sauer, R.T., 2003. OMP peptide signals initiate the envelope-stress response by activating DegS protease via relief of inhibition mediated by its PDZ domain. Cell 113(1), 61-71. https://doi.org/10.1016/S0092-8674(03)00203-4 
Wellstein, C., Poschlod, P., Gohlke, A., Chelli, S., Campetella, G., Rosbakh, S., Canullo, R., Kreyling, J., Jentsch, A., Beierkuhnlein, C., 2017. Effects of extreme drought on specific leaf area of grassland species: A meta-analysis of experimental studies in temperate and sub-Mediterranean systems. Global Change Biology 23(6), 2473-2481. https://doi.org/10.1111/gcb.13662

Wickham, H., 2016. ggplot2: Elegant Graphics for Data Analysis. Biometrics 67, 678-679. https://doi.org/10.1111/j.1541-0420.2011.01616.x

Wilke, A., Harrison, T., Wilkening, J., Field, D., Glass, E.M., Kyrpides, N., Mavrommatis, K., Meyer, F., 2012. The M5nr: A novel non-redundant database containing protein sequences and annotations from multiple sources and associated tools. BMC Bioinformatics 13, 1-5. https://doi.org/10.1186/1471-2105-13-141

Xiong, Z.J., Zhang, J.L., Zhang, D.F., Zhou, Z.L., Liu, M.J., Zhu, W.Y., Zhao, L.X., Xu, L.H., Li, WJ, 2013. Rothia endophytica sp. nov., an actinobacterium isolated from Dysophylla stellata (Lour.) benth. International Journal of Systematic and Evolutionary Microbiology 63, 3964-3969. https://doi.org/10.1099/ijs.0.052522-0

Xu, L., Naylor, D., Dong, Z., Simmons, T., Pierroz, G., Hixson, K.K., Kim, Y.M., Zink, E.M., Engbrecht, K.M., Wang, Y., Gao, C., DeGraaf, S., Madera, M.A., Sievert, J.A., Hollingsworth, J., Birdseye, D., Scheller, H. V., Hutmacher, R., Dahlberg, J., Jansson, C., Taylor, J.W., Lemaux, P.G., Coleman-Derr, D., 2018. Drought delays development of the sorghum root microbiome and enriches for monoderm bacteria. Proceedings of the National Academy of Sciences of the United States of America 115(18), E4284-E4293. https://doi.org/10.1073/pnas.1717308115

Young, C.C., Lin, S.Y., Arun, A.B., Shen, F.T., Chen, W.M., Rekha, P.D., Langer, S., Busse, H.J., Wu, Y.H., Kämpfer, P., 2009. Algoriphagus olei sp. nov., isolated from oil-contaminated soil. International Journal of Systematic and Evolutionary Microbiology 59(11), 2909-2915. https://doi.org/10.1099/ijs.0.009415-0

Zerbino, D.R., 2010. Using the Velvet de novo assembler for short-read sequencing technologies. Current Protocols in Bioinformatics 31(1), 11.5.1-11.5.12. https://doi.org/10.1002/0471250953.bi1105s31 
Zhang, X., Cai, X., 2011. Climate change impacts on global agricultural land availability. $\begin{array}{llll}\text { Environmental } & \text { Research } & \text { L(1), }\end{array}$ https://doi.org/10.1088/1748-9326/6/1/014014

Zhang, Y., Xu, J., Wang, E., Wang, N., 2020. Mechanisms underlying the rhizosphere-to-rhizoplane enrichment of Cellvibrio unveiled by genome-centric metagenomics and metatranscriptomics. Microorganisms 8(4), 583. https://doi.org/10.3390/microorganisms 8040583

\section{CRediT author statement}

Using CRediT (Contributor Roles Taxonomy). Cristóbal Hernández-Álvarez: Conceptualization, Methodology, Visualization, Formal Analysis, Investigation, Writing-Original Draft. Felipe García Oliva: Conceptualization, Supervision. Rocío Cruz-Ortega: Investigation, Supervision, Resources. Miguel F. Romero: Formal analysis. Hugo R. Barajas: Resources, Formal Analysis. Daniel Piñero: Conceptualization, Funding acquisition, Resources. Luis D. Alcaraz: Conceptualization, Supervision, Funding acquisition, Project administration, Visualization, Writing - Reviewing and Editing. 


\section{Supplementary figures}

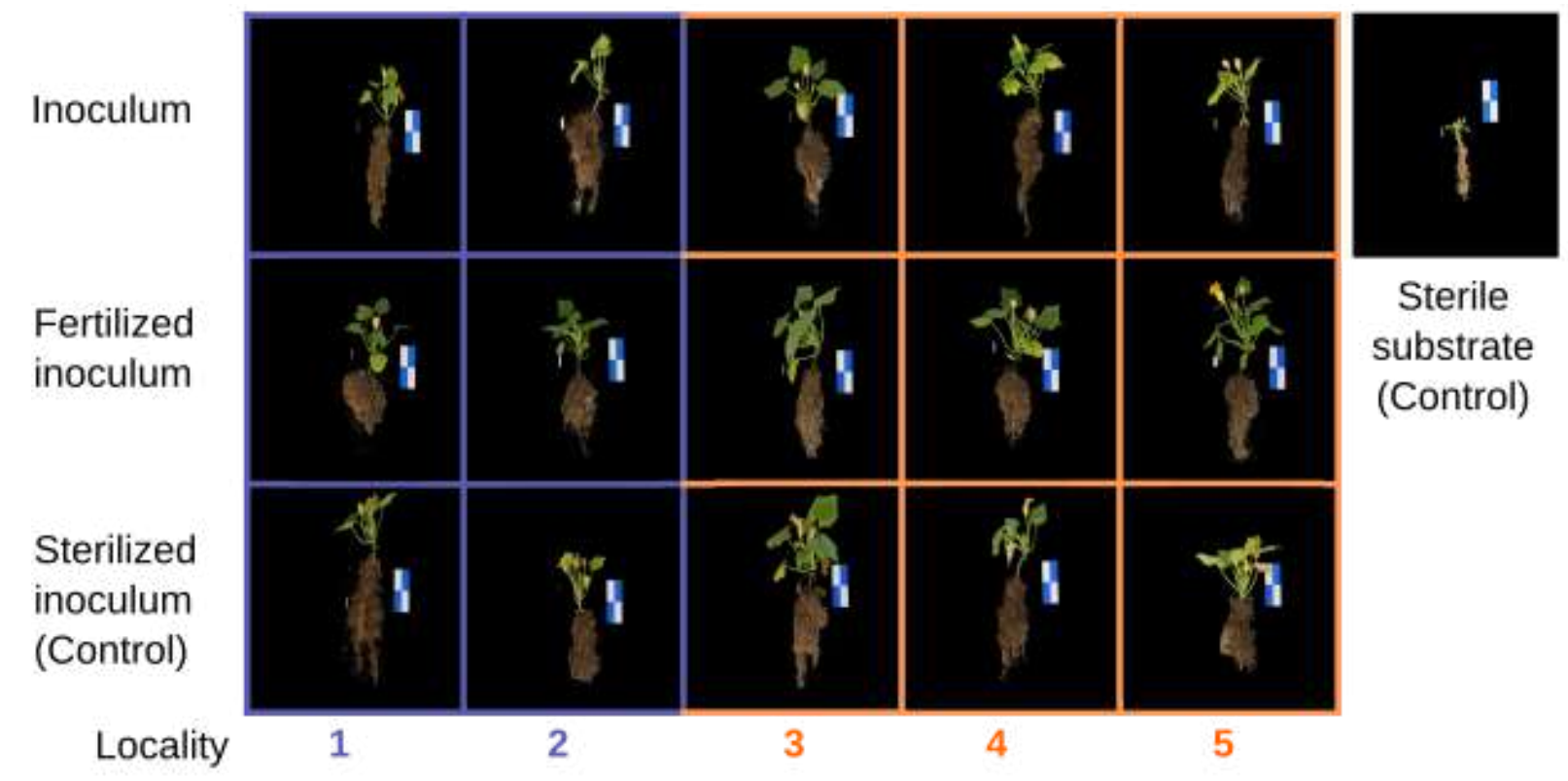


Figure S1 Common garden experiment plants after 52 days. The rectangles color indicates if the plants were grown on humid (blue) or arid (orange) inoculums. In the right upper corner, a plant grown without soil inoculum in sterilized substrate.

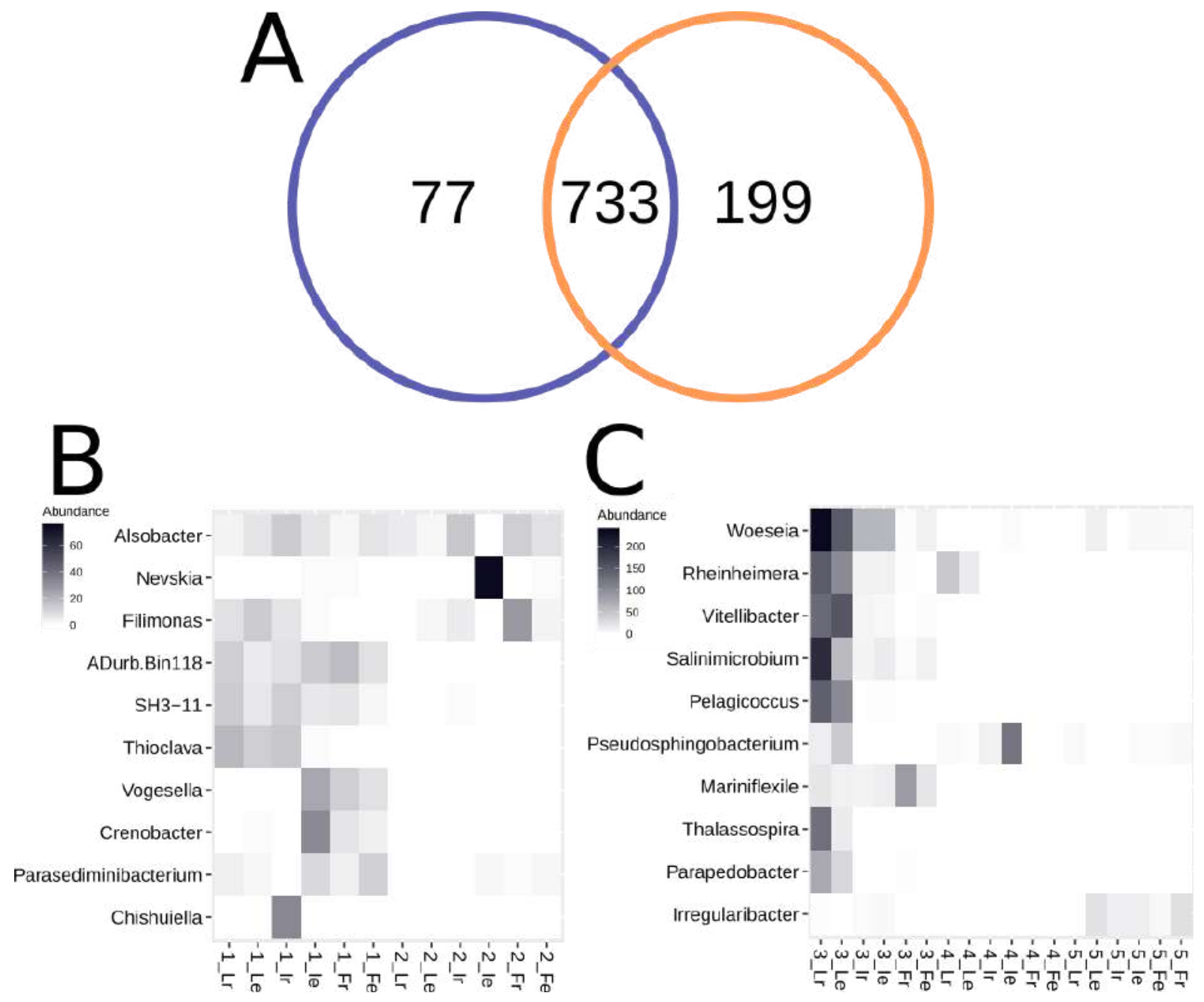

Figure S2. Bacterial genera from historically arid and humid plant-associated samples.

A) Venn diagram contrasting both conditions. B) Most abundant genera from historically humid plant-associate samples. C) Most abundant genera from historically arid plant-associate samples. 

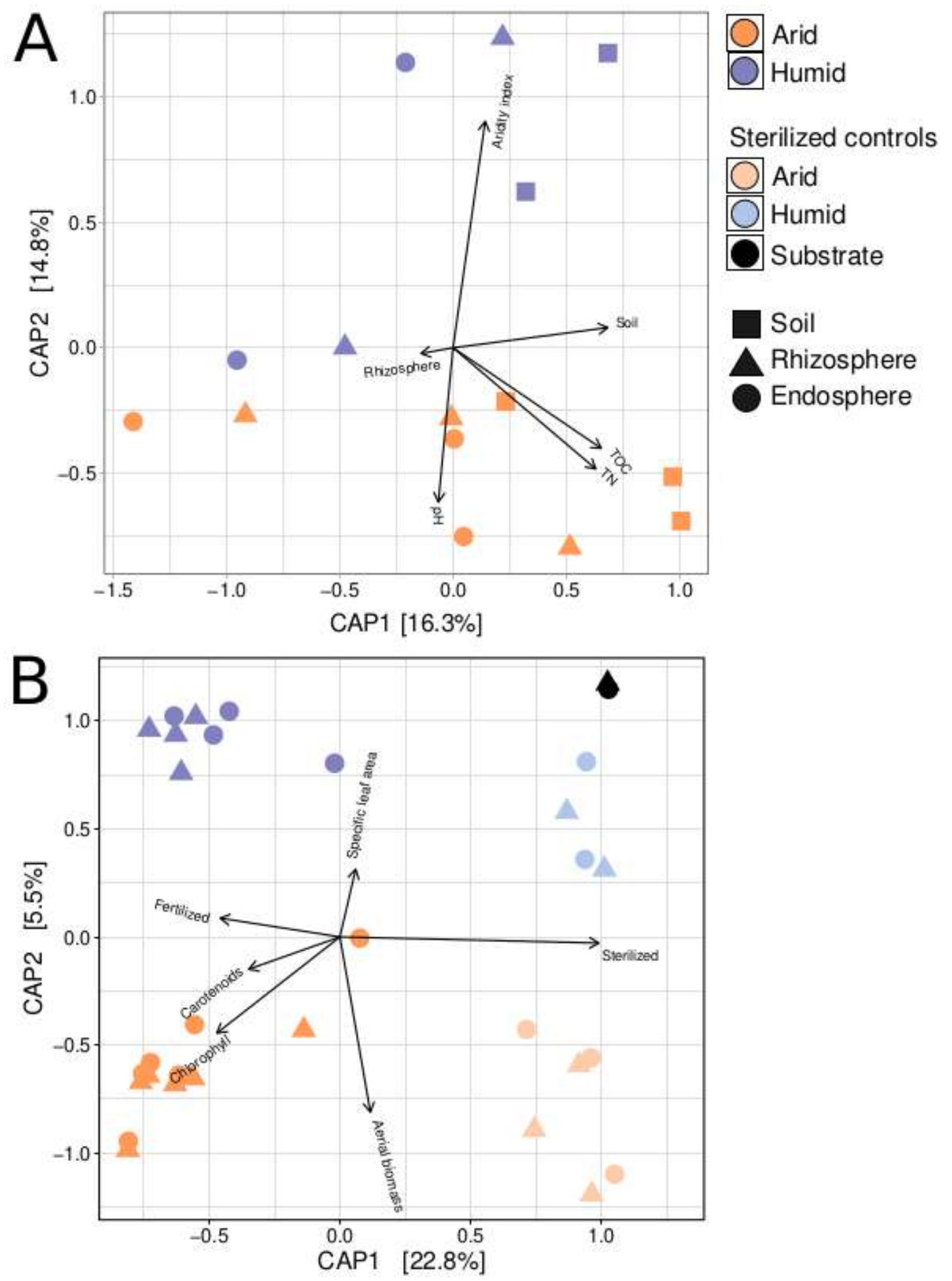

Figure S3. Differences between bacterial communities originated from historically humid and arids localities. A) CAP ordination based on unweighted Unifrac distances between common garden experiment samples and plant phenotype. B) CAP ordination of 
unweighted Unifrac distances from local source samples and environmental parameters (AI and physicochemical characterization of soils). Arrows indicate a correlation to variables. TN, total nitrogen; TOC, total organic carbon.

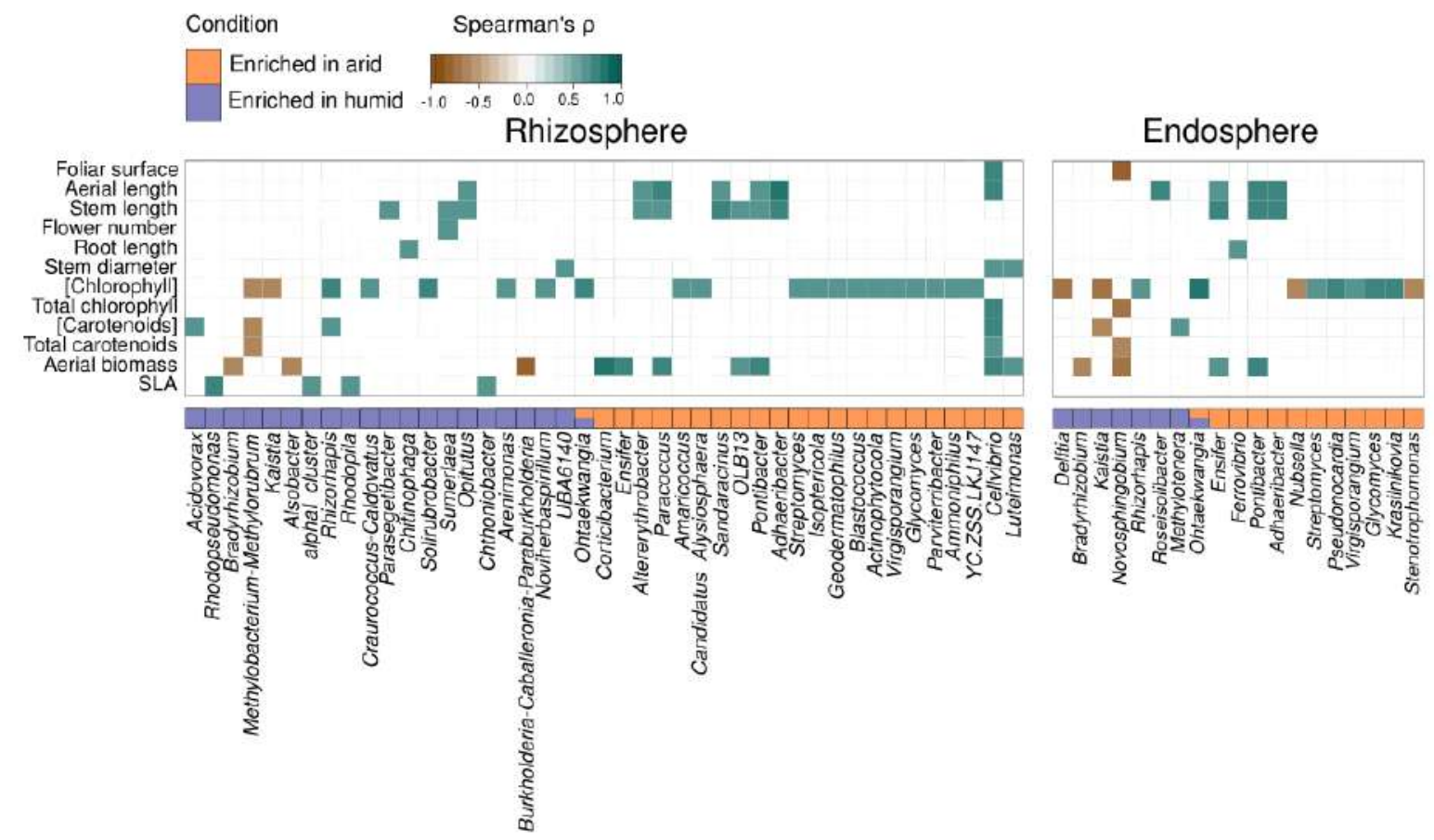


Figure S4. Correlation between relative abundance of genera enriched in arid or humid soils and plant phenotype. The correlations were evaluated for root-associated bacteria that were enriched in historically arid and humid soils (based on DESeq2 analyses). Only statistically significant values ( $P \leq 0.05$, FDR), not significant values are covered by a white square. 


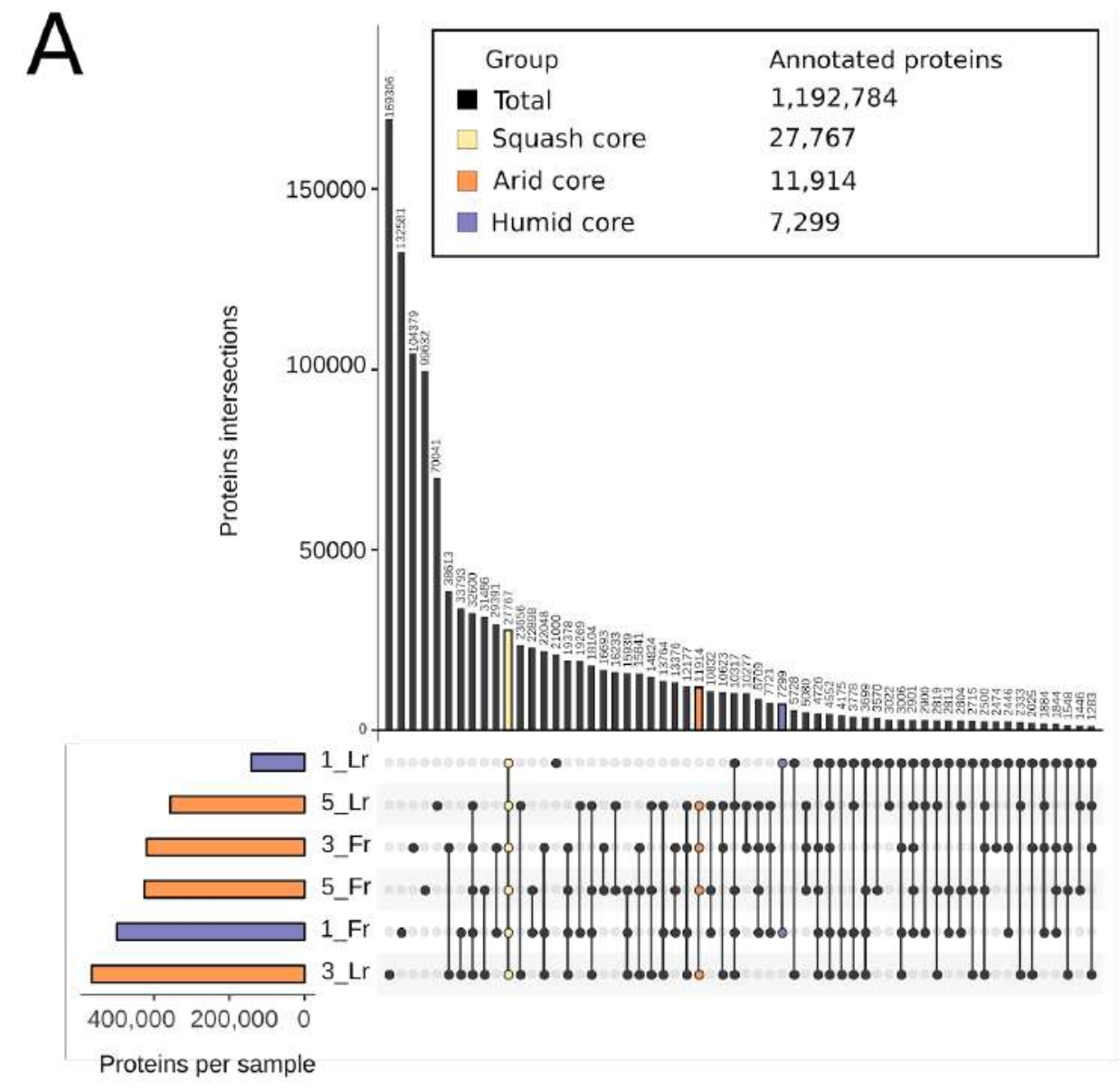

B

Signal transduction histidine kinas Citrate synthase Microcin C transport system substrate-binding-protein Citrate synthase/ methylcitrate synthase CocE/NonD family hydrolase

Sulfatase modifying factor 1 precurso Filamentation induced by CAMP protein Fic Response regulator/sensor histidine kinase Glycine/serine hydroxymethyltransferase Osmosensitive $\mathrm{K}+$ channel histidine kinase Beta-lactamase Taurine catabolism dioxygenase TauD/TfdA Peptidase M16 domain protein Peptidase S46

Glutamate synthase (NADH) large subunit Efflux transporter, RND family, MFP subunit Beta-lactamase Membrane protein insertase YidC ATP-dependent helicase HrpA RHS Repeat family Phosphoenolpyruvate carboxylase Hypothetical protein DNA ligase, NAD-dependent Tex-like protein

Diguanylate cyclase/phosphodiesterase Alpha-2-macroglobulin family $\mathrm{N}$-terminal region family TonB-dependent receptor

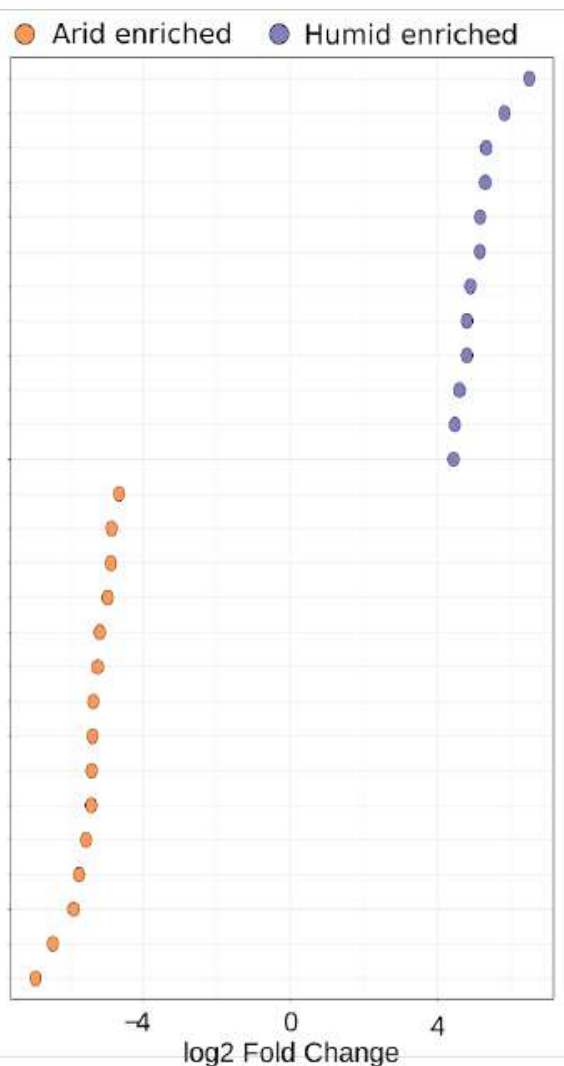


Figure S5. Comparative analysis of predicted proteins (RefSeq) from root-associated communities recruited from historically humid and historically arid locations. A) Upset plot contrasting predicted proteins according to the climatic source. Arid and humid cores are defined as the set of predicted proteins present in all samples from the same climatic source. Squash core refers to predicted proteins shared by the whole set of samples. B) DESeq2 analysis between both climatic conditions from squash core metagenome $(p \leq 0.05)$. 


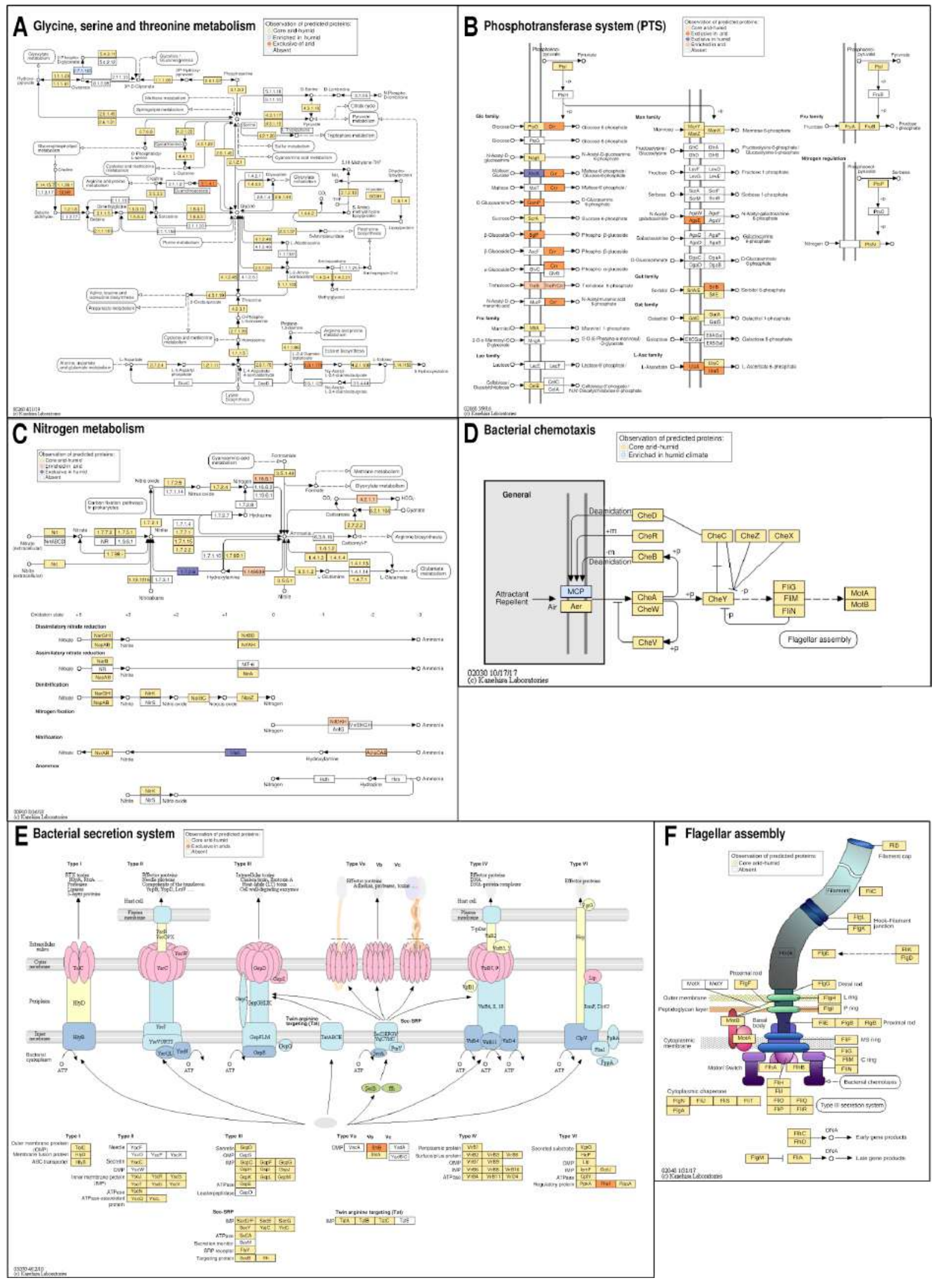


Figure S6. Metabolic pathway reconstructions of predicted proteins, using KEGG Mapper. A) Glycine, serine and threonine metabolism. B) Phosphotransferase system. C) Nitrogen metabolism. D) Bacterial chemotaxis. E) Bacterial secretion system. F) Flagellar assembly. Core humid arid was defined as the set of proteins shared between both climatic conditions of source samples. Enriched proteins were determined according to DESeq2 analysis.

\section{Supplementary tables}

Upon request.

Table S1 Plant phenotypic traits evaluated in the common garden experiment. Phenotypic traits evaluated in the common garden experiment. Names are composed of in situ soil sampling localities (1-5) and treatment: soil inoculants (I), fertilized soil inoculants (F), sterilized soil controls (Z), and no soil control (C).

Table S2 Sequencing, richness and diversity from 16S rRNA V3-V4 sequences. Names are composed by the number of localities, treatment and sample type. Localities are numbered from 1-5 from the most arid to the most humid. Treatments are local source samples $(L)$, soil inoculum (I), fertilized inoculum (F), sterilized inoculum $(Z)$ and controls without soil (C). Sample types are soil (s), rhizosphere (r), endosphere (e) and without plant (n).

Table S3 Metagenomic sequencing, filtering, assembly and diversity of predicted proteins. Names are composed by the number of localities, treatment and sample type. Selected 
localities were $1,2,3$. Treatments are local source samples $(L)$ and fertilized inoculum (F) from rhizospheres $(r)$.

Table S4 Comparative analysis between shared and unique genera from the rhizosphere and the root endosphere

Table S5 Differential (DESeq2) endosphere OTUs in humid-arid comparisons.

Table S6 Enriched (DESeq2) rhizosphere OTUs in humid-arid comparisons.

Table S7 Cucurbita pepo core microbiome

Table S8 Percentage of metagenomic sequences aligned against reference genomes. Reference genomes are sorted according to the average percentage of sequences aligned against mategenomes. Only reference genomes aligned with an average percentage of aligned sequences greater than $5 \%$ are shown.

Table S9 Exclusive Subsystems in whole metagenomic sequences from rhizosphere according to climatic origin from soil samples.

Table S10 Differential (DESeq2) humid-arid comparison rhizosphere genes (Subsystems).

Table S11 Differential (DESeq2) humid-arid comparison rhizosphere genes (Kegg Orthologs).

Table S12 Exclusive Kegg Orthologs (KOs) in whole metagenomic sequences from the rhizosphere according to climatic origin from soil samples. 